\title{
Shades of Gray: Internal Control Reporting by Chinese U.S.-listed Firms
}

\author{
RAYMOND REED BAKER ${ }^{\text {a* }}$ \\ GARY C. BIDDLE \\ MICHELLE RENÉ LOWRYc \\ NEALE G. O'CONNOR
}

May 30, 2018

${ }^{a}$ School of Economics and Management, Tongji University, Ray.Baker@OneWorldIG.com, Tel : +1 713893-3501

${ }^{\mathrm{b}}$ Faculty of Business and Economics, University of Melbourne, g.biddle@ unimelb.edu.au, Tel : +61 38344 9807 Fax : +61393492397

${ }^{\mathrm{F}}$ Faculty of Business and Economics, University of Hong Kong, Pokfulam, Hong Kong, michelle.rene.lowry@hku.hk, Tel : +85254114546 Fax : +852 28585614

${ }^{\mathrm{d} S c h o o l}$ of Business, Monash University, Malaysia, neale.oconnor@monash.edu, Tel : +60 122005964 Fax : +60355146326

*Dr. Baker is founder and managing director of One World International Group, a China-based consulting firm specializing in U.S.-compliant corporate governance and reporting. All data are available from public sources. We are grateful for helpful comments made by seminar participants at the American Accounting Association Annual and International Accounting Section Meetings, Accounting Horizons China Forum, National University of Singapore, Ohio State University, University of Hong Kong, and the China Securities Market and Valuation Conference at Hong Kong University of Science and Technology. We also thank Tom Hardy for insights and feedback regarding Audit Analytics data. Any errors remain our responsibility. 


\section{Shades of Gray: Internal Control Reporting by Chinese U.S.-listed Firms}

Chinese firms listing in the U.S. via reverse mergers (CRMs) have dominated prior media, regulator and research attention. Yet CRMs have effectively ceased, leaving Chinese firms listing via initial public offerings (CIPOs) as the relevant remaining class of Chinese firms listing on U.S. exchanges. This study documents salient differences between CIPOs, CRMs and U.S.-domiciled U.S.-listed firms by examining Sarbanes-Oxley Act Section 302 and 404(b) ineffective internal control (IIC) and related disclosures that underlie financial reporting quality, with three main sets of findings. First, both CIPOs and CRMs are more likely to report IICs than U.S.-domiciled counterparts. Second, both CIPOs and CRMs are more likely to under-report IICs than U.S.-domiciled counterparts (CIPO for only 302 disclosures). Third, CIPOs are both less likely to report and less likely to under-report IICs than CRMs. These findings clarify and recast prior characterizations of the internal controls underlying the reporting quality of Chinese U.S.-listed firms.

Keywords: Sarbanes-Oxley Act; International Cross-Listing; China; Internal Controls; Chinese U.S.-listed Firms; Reverse Mergers

JEL Classifications: G18, G34, G38, M41, M42, M48 


\section{Shades of Gray: Internal Control Reporting by Chinese U.S.-listed Firms}

\section{INTRODUCTION}

Chinese U.S.-listed firms have attracted considerable media, regulator and research attention amid allegations of financial reporting weaknesses. ${ }^{1}$ To date, attention has focused on Chinese firms listing in the U.S. via reverse mergers (CRMs) ${ }^{2}$ rather than via initial public offerings (CIPOs). Yet CIPOs merit separate consideration for several reasons. First, prior findings regarding the financial reporting of CRMs may not generalize to CIPOs due to differences in firm characteristics and listing scrutiny. Second, new CRM listings have virtually ceased as CIPO listings continue, leaving CIPOs as the relevant remaining class of Chinese U.S. listers (Shih 2015; Thomas and Barreto 2014). Third, the market value of CIPOs far exceeds that of CRMs. ${ }^{3}$ Finally, whereas prior evidence finds CRM financial reporting concerns "spilled over" to CIPOs (Ang, Jiang, and Wu 2014; Darrough et al. 2015), little evidence exists regarding internal control differences that may help explain these findings. This study compares the internal control reporting of CIPOs with that of CRMs and U.S. domiciled U.S.-listed firms to document salient shades of gray in internal controls that extend and re-cast prior findings regarding the financial reporting quality of Chinese U.S.-listed firms.

We examine both Sarbanes-Oxley Act (SOX) Section 302 and Section 404(b) ineffective internal control reports (hereafter 302 and 404(b), respectively, and IICs collectively), which allows for assessments of under-reporting and a larger sample size. Whereas 404(b) reports are annual disclosures that are the

\footnotetext{
${ }^{1}$ Representative headlines include "Chinese stock scams are the latest U.S. import" (Vlastelica \& Bases, Reuters, May 11, 2011), "China's U.S.-listed stocks are junk" (Stephen, Market Watch, July 10, 2011), "Falling out of love with China" (Sternberg, Wall Street Journal, November 17, 2011). In 2010, the PCAOB drew their attention to the auditors of CRMs in both a Staff Audit Practice Alert and through a meeting of the Board's Standing Advisory Group (PCAOB 2010). See Section 5 for a discussion of heightened scrutiny of Chinese U.S.-listed firms beginning in 2010.

${ }^{2}$ In our study period, Chinese firms have constituted fully half of U.S. foreign initial public offerings and over 80 percent of foreign reverse merger listings (Gao, Ritter, and Zhu 2013; Givoly, Hayn, and Lourie 2014). A reverse merger occurs when an operational private company acquires a publically listed shell company, with little or no assets, and then injects private company assets into the public shell, effectively circumventing the IPO vetting process. In addition to this lower oversight, reverse mergers are also faster to complete and less expensive than listings via IPOs. See Lee, Li, and Zhang (2015) and Chen, Cheng, Lin, Lin, and Xiao (2016) for further background on reverse mergers. Prior studies that focus primarily on CRMs include Lee et al. (2015), Darrough, Huang, and Zhao (2015), Chen et al. (2016), and Mao and Ettredge (2016).

${ }^{3}$ Our sample, which is biased toward including relatively high value CRMs, shows CIPOs to have 8.5 times higher average market value than CRMs, and these size differences preceded the fraud crisis beginning in 2010.
} 
statutory responsibility of external auditors, 302 reports are filed quarterly and are the statutory responsibility of firm managers. 302 reports provide greater coverage of Chinese U.S.-listed firms, since approximately half are non-accelerated SEC filers, and thus exempt from 404(b) reporting examined in most prior studies.

To explain the IIC reporting patterns of CIPOs, CRMs and matched U.S.-domiciled U.S.-listed counterparts, we apply predictions from cultural influence and reputational bonding theory. When applied to Chinese U.S.-listed firms, cultural influence predicts that they will report more IICs, and under-report more IICs, than comparable U.S.-domiciled U.S.-listers. ${ }^{4}$ When applied to CIPOs that self-select to list via more arduous "front door" listing procedures, reputational bonding predicts lower CIPO IIC reporting, and lower under-reporting, in comparison to CRMs that use expedited "back-door" listings. As explained in Section 2, countervailing institutional features of the China context render predictions of reputational bonding more nuanced than for non-Chinese foreign U.S.-listers previously studied.

We control for firm characteristics when testing for IIC reporting and under-reporting using the determinant model of Ashbaugh-Skaife, Collins, and Kinney Jr (2007) (ACK) and matched sample analyses for 2008-2012, with several new findings. ${ }^{5}$ First, consistent with cultural influence predictions, we find that both CIPOs and CRMs are more likely to report IICs than domestic public U.S. firms (H1). Second, using an under-reporting measure following Gong, Ke, and $\mathrm{Yu}$ (2013), we find that both CIPOs and CRMs are more likely to under-report IICs than U.S.-domiciled U.S.-listed firms (H2), and CIPOs are only more likely to under-report 302 disclosures consistent with auditor influence on the decision to under-report. Third, we find that CIPOs are less likely than CRMs to report IICs (H3). Fourth, we document that CIPOs are less

\footnotetext{
${ }^{4}$ As highlighted by the Public Company Accounting Oversight Board (PCAOB) during the scrutiny period, "weak internal controls and lack of robust governance mechanisms have been observed in companies in certain emerging market countries. This may stem from a lack of familiarity in local cultures with certain governance concepts, such as prohibition of self-dealing, even where similar legal concepts exist. For example, such a culture might provide opportunities for management to influence other senior company officials or various third parties to provide false or misleading information to the company's auditors. If criticizing or questioning a figure of authority is contrary to the local culture, the company's employees may be hesitant to express any concerns about management's actions to an auditor. Such an environment can provide additional opportunities for management to override controls or intentionally misstate the financial statements" (page 8, PCAOB SAPA No. 8, 2011). See related discussion in Section 6.

${ }^{5}$ After 2012, there are few new CRMs, and many existing CRMs ceased to file with the SEC, either by going private or otherwise going "dark", with Robertson (2015) characcterizing CRMs as fading into history.
} 
likely than CRMs to under-report IICs for 404(b) disclosures (H4). Tests for the effect of regulator and media scrutiny on IIC reporting and descriptive data regarding IIC types and auditors provide additional support for these findings. Thus, this study reveals salient differences in internal controls underlying the financial reporting quality of CIPOs versus the previously more studied CRMs, and between CIPOs, CRMs and their U.S.-domiciled U.S.-listed counterparts.

These findings extend several research streams. First, they document clear differences in IIC reporting regarding internal controls that underlie financial reporting quality for previously studied CRMs and CIPOs, which now constitute the relevant remaining class of Chinese foreign listers. Second, evidence of IIC reporting and under-reporting by both CIPOs and CRMs compared with matched U.S.-domiciled U.S. listers helps explain prior spillover, short-selling, and incomplete investor discrimination effects (Ang et al. 2014; Darrough et al. 2015), and helps to answer Ang et al.'s $(2014,2)$ question of "Why did US investors and analysts indiscriminately dump all Chinese shares?" as investors could not have easily differentiated between "good and bad apples". These findings further help explain Lee et al.'s (2015) findings regarding CRM performance compared with U.S. counterparts since reported performance is a function of financial reporting quality. Third, our finding that CRMs are more likely to report IICs complements Srinivasan, Wahid, and Yu's (2014) inference that the use of restatements to infer CRM 302 under-reporting is problematic (Mao and Ettredge 2016). Fourth, our findings have regulatory implications in documenting differences between CIPOs and CRMs in both IIC reporting and under-reporting, and in highlighting the importance of auditor assessments of manager-disclosed IICs in light of 404(b) exemption for foreign non-accelerated filers, particularly for Chinese U.S.-listed firms.

Our results also provide evidence on whether SOX internal control provisions have been effective in meeting their stated goals for Chinese U.S.-listed firms. ${ }^{6}$ In particular, our findings of higher IIC reporting and under-reporting by both CIPOs and CRMs compared with U.S.-domiciled U.S. listers indicate that

\footnotetext{
${ }^{6}$ Per PCAOB member Jeannette Frazel, "The Sarbanes-Oxley Act was enacted to provide better protection for investors by improving the reliability of corporate financial reporting and disclosures under the securities laws. Continued research and analysis are important to assess how breakdowns occurred in auditing and governance systems" $(2011,924)$.
} 
SOX provisions have been to some degree ineffective for Chinese listers. Our auditor evidence complements previously observed associations between auditor quality and internal controls (AshbaughSkaife et al. 2007; Ettredge, Heintz, Li, and Scholz 2011) in justifying PCAOB concerns regarding the audit quality of Chinese U.S.-listed firms (PCAOB 2010). With Chinese firms again exhibiting underperforming shares in the U.S. (Russolillo and Driebusch 2017) and increasingly listing on other stock exchanges, including via reverse mergers on China's own exchanges (Ren 2016; Yu 2016), our findings will help inform research, audits, regulations, and interpretations of the financial reporting of these prominent and controversial listers in the U.S. and globally.

In Section 2, we present the context and theory that motivate our hypotheses. In Section 3, we describe our hypothesis tests. In Section 4, we present sample selection procedures and descriptive statistics, and in Section 5, we discuss the results. Section 6 presents supplementary analyses and Section 7 provides a concluding discussion.

\section{BACKGROUND, THEORY AND HYPOTHESES DEVELOPMENT}

U.S. listings by Chinese domiciled firms began in earnest in the early 1990s. By the mid-2000s, this "coming out party" (Hennock 2004) had attracted considerable U.S. investor interest in stocks that ostensibly combined China's rapid growth, international diversification and financial reporting overseen by the U.S. Securities and Exchange Commission (SEC). Chinese firms were drawn to U.S. stock markets for capital, liquidity, and listing provisions unavailable in $\mathrm{China}^{7}$, and soon constituted fully half of U.S. foreign initial public offerings and over 80 percent of foreign reverse merger listings (Gao et al. 2013; Givoly et al. 2014). Yet these apparent benefits were overtaken in 2010 by media scrutiny and regulator accusations of financial reporting improprieties by Chinese U.S.-listed firms (Holmes 2010), leading the Bloomberg China-U.S. Equity Index to plunge 58.5 percent over a five-and-a-half month period (Yuk and Massoudi

\footnotetext{
${ }^{7}$ For example, dual-class shares are not presently permitted by Hong Kong, Shanghai and Shenzhen stock exchanges, which was a deciding factor in Alibaba's decision to list in the U.S. instead of in China.
} 
2013). These financial reporting concerns brought Chinese U.S.-listed firms, auditors, exchanges and regulators to loggerheads as Chinese firms' access to capital plummeted (Ang et al. 2014). Related reporting and regulatory responses reverberate to the present, including U.S. de-listings by CRMs, re-listings in China stymied by IPO restrictions and high volatility (Osawa and Wei 2015), a Chinese government-mandated freeze on and subsequent promotion of IPO listings (Chen and Zhang 2017; Ren 2016; Yu 2016), and market interventions leading to a nearly 50 percent drop in the Shanghai index during 2015-16, all of which benefits from evidence regarding internal controls and internal control reporting by CIPOs and CRMs. ${ }^{8}$

\section{CIPO and CRM Literature}

Prior evidence regarding the financial reporting quality of Chinese U.S.-listers has focused primarily on CRMs. Chen et al. (2016) find weaker financial reporting quality and corporate governance for CRMs compared with matched U.S. IPOs and CIPOs, but do not examine CIPOs separately. Mao and Ettredge (2016) find CRMs to have a higher likelihood of filing adverse 302 reports but no difference in CRM likelihood to file an adverse 302 report compared with other U.S.-listed firms when internal control weakness exists as proxied by a subsequent restatement. However, Srinivasan et al. (2014) find evidence of opportunistic under-reporting of restatements by foreign listers, which together with a higher baseline of 302 reporting by CRMs, confounds the use of restatements as a benchmark for 302 under-reporting. Lee et al. (2015) find the performance and survival of CRMs to exceed that of U.S. reverse merger firms (USRMs) during three years following listings. However, Lee et al. do not examine CIPOs, and because poor CRM financial reporting quality could have boosted reported performance and delayed de-listings, an alternative explanation is that investors were less able to distinguish good from bad apples as characterized by Ang et al. (2014). As such, little prior evidence exists in the literature regarding the internal controls and financial reporting quality of CIPOs separate from CRMs.

\footnotetext{
${ }^{8}$ Representative headlines include "China Reconsiders the Homecoming Party" (Cao and Xie 2016) and "Chinese Regulator Probes Six Companies in IPO Fraud Crackdown” (Gao 2016).
} 
We extend this literature by comparing the 302 and 404(b) IIC disclosures of CIPOs, CRMs, and domestic U.S.-listed matched counterparts, explicitly testing for differences in IIC reporting and underreporting and for the effects of increased media and regulatory scrutiny. As corroborating evidence, we also document their auditors and types of IICs disclosed. Our study thus helps address whether prior findings

for CRMs apply to Chinese U.S.-listed firms that are increasingly CIPOs, and whether differences between CIPOs and CRMs can help explain prior findings and questions regarding the financial reporting of Chinese U.S.-listed firms (e.g., Ang et al. 2014; Darrough et al. 2015).

\section{IIC Reporting Requirements}

Sections 302 and 404 of SOX substantially enhanced U.S. financial reporting requirements regarding internal controls (Engel, Hayes, and Wang 2007; Zhang 2007). Specifically, Section 302 requires managers of U.S.-listed firms to assess and report their firms' IICs quarterly to the SEC. Section 404(a) requires managers to annually document, test, conclude, and report on the effectiveness of internal controls. Section 404(b) requires external auditors to assess and attest to their clients' internal controls annually. In this study we examine both 302 reports, which by nature are subject to less auditor oversight, and 404(b) attestation reports, so as to provide evidence regarding external auditor influence. ${ }^{9}$ Legislators and regulators envisioned that the resulting higher quality internal controls induced by SOX Section 302 and 404 reporting would enhance financial reporting quality and regulatory compliance (SOX, 2002). Subsequent research indicates that effective internal controls are associated positively with financial reporting quality (Goh and Li 2011) and accruals quality (Doyle, Ge, and McVay 2007b; Ashbaugh-Skaife, Collins, Kinney, and LaFond 2008). However, differences in cultural, institutional, and legal contexts may

\footnotetext{
${ }^{9}$ Although 302 reports are arguably "a function of managers' diligence in identifying weaknesses and in their discretion over disclosure" (Beneish, Billings, and Holder, 2007, p. 668), 302 reports are more timely than 404(a) reports and provide information regarding quarterly internal control issues, which can be remediated by year end, resulting in a clean 404(a) report. In addition, fourth quarter 302 reports are found to be consistent with 404(a) reports in a prior study (Mao and Ettredge 2016) and in this study's sample. Further, regulator guidance in 2007 has provided clarity for 302 reporting and may be the reason for an increase in 302 IIC reporting (Munsif, Raghunandan, and Rama 2013).
} 
induce managers of Chinese U.S.-listed firms to interpret and implement IIC reporting requirements differently than U.S.-domiciled and listed counterparts as we detail next.

\section{Cultural Influences on IIC Reporting}

Prior research confirms that national culture is an informal institution that influences financial reporting practices (Salter and Niswander 1995) beyond formal institutional environment effects (Peng, Wang, and Jiang 2008). Specifically, collectivistic cultures like China's (Tu, Lin, and Chang 2011; Hofstede 2007) have been found to have higher differential treatment of in-groups and out-groups. Thus, Chinese managers are more likely to favor the interests of the organization or concentrated owners (their in-group) relative to foreign investors (their out-group), and, they are likely to place less emphasis on the importance of financial disclosures and transparency for such investors as suggested by Chow, Deng, and Ho (2000) and Triandis, Bontempo, Villareal, Asai, and Lucca (1988). Cullen, Parboteeah, and Hoegl (2004) present large-scale multinational survey evidence that national cultural values of individualism and achievement (universalism and pecuniary materialism) reduce (increase) a manager's tendency to justify ethically questionable behaviors; Cullen et al. (2004) find similar effects for the degree of educational attainment. Given that China is generally less individualistic culturally, with less developed investor protection provisions, these prior findings suggest that Chinese managers may be less attuned to SOX's internal control reporting objectives, requirements and enforcement provisions regarding internal control systems and IIC disclosures, which may lead to more underlying IICs and less incentive to report them.

A complementary cultural aspect that can influence IIC reporting is advocacy participation. Advocacy participation refers to a willingness to speak out to effect beneficial change in an organization (Van Dyne and LePine 1998). Although advocacy participation is commonly viewed as constructive in Western organizations (Van Dyne and LePine 1998; Turnipseed and Rassuli 2005), Farh, Chen-Bo, and Organ (2004) find it largely absent in organizational citizenship behaviors in Chinese companies. Farh et al. (2004) argue that China's interpersonal relationships are more characterized by single group networks that make conflict riskier because escalation can lead to social alienation. Relatively lower levels of 
advocacy participation in Chinese firms may thus reduce the effectiveness of SOX in incentivizing strong internal controls, again indicating more IICs and less incentive to report them.

Applying these insights from cultural influence research, we propose as a framing hypothesis in alternate form that both CIPOs and CRMs are more likely to report IICs than their U.S.-domiciled counterparts, ceteris paribus:

Hypothesis 1. CIPOs and CRMs are more likely to report IICs than U.S.-listed U.S.-domiciled firms.10

\section{Cultural and Institutional Influences on IIC Under-Reporting}

Following from the discussion and evidence above, cultural factors that may lead to weaker internal controls may similarly motivate under-reporting of IICs once discovered, although prior evidence is again limited for CIPOs. For example, Srinivasan et al. (2014) provide evidence that weak home-country investor protections can lead to opportunistic under-restating of financial reports. Using a sample of U.S. firms that restated their financial results, Rice and Weber (2012) show over half under-reported 404(b) IICs, but they did not specifically examine Chinese U.S.-listed firms. Gong et al. (2013) investigate the effect of excess voting rights over cash flow rights of concentrated owners on IIC misreporting by cross-listed firms in weak institutional environments. With only seven Chinese firms in their sample, they do not draw inferences regarding their IIC under-reporting, nor do they examine the effect of their listing methods.

An institutional feature applicable to Chinese U.S.-listers in particular is historically lower enforcement risk due to the barriers U.S. regulators have faced in conducting China-related investigations. This condition is exemplified by the U.S.-China Economic and Security Review Commission's 2005 annual report, which explicitly recommended to the U.S. Congress that the SEC work with foreign regulatory counterparts to enhance enforcement of securities regulations (USCC 2005). However, the SEC took no immediate action to protect investors from the predicted systemic risk amid accumulating complaints

\footnotetext{
${ }^{10}$ Mao and Ettredge (2016) find CRMs to be more likely to disclose 302 IIC reports than other listed firms. We likewise examine CRMs when testing Hypothesis 1 both to benchmark our findings with prior results and to validate that this relation for 302 disclosures is also associated with 404 (b) reports that we also examine.
} 
regarding the financial reporting of Chinese U.S.-listed firms. When the SEC began to discipline Chinese U.S.-listed firms in 2010 (Eden and Holmes 2010), the Chinese Securities Regulatory Commission (CSRC) responded by prohibiting their auditors from providing requested audit documents to SEC fraud investigations, thereby impeding enforcement (Shih 2013). Although the PCAOB and the CSRC signed an agreement in 2013 allowing the PCAOB to access certain audit documents, which are first CSRC-screened, access is still incomplete and tenuous (Commons and Goldman 2014; PCAOB 2016). This resulting weaker enforcement of nominally strong financial reporting requirements for Chinese U.S.-listed firms may have reduced managerial incentives to self-report IICs under Section 302 relative to perceived enforcement exposure under Section 404(b) for their auditors. We utilize these differential reporting incentives between SOX 302 and 404(b) as a design feature below. Applying this reasoning, we provide evidence regarding potential under-reporting of IICs by Chinese U.S.-listed firms by testing the following hypothesis, ceteris paribus:

Hypothesis 2. CIPOs and CRMs are more likely to under-report IICs than U.S.-listed U.S.-domiciled firms.

If Chinese U.S.-listed firms under-report extant IICs for whatever reasons, including cultural influence, weaker corporate governance, unfamiliarity with U.S. reporting provisions, and/or perceptions of weak prior enforcement as discussed above, it will bias findings against the hypothesized relations in H1. As such, evidence that supports $\mathrm{H} 2$ by construction also provides support for $\mathrm{H} 1$.

\section{Reputational Bonding Theory}

Reputational bonding theory further supports distinctions between CIPOs and CRMs in internal control system design and reporting. Specifically, Siegel (2005) proposes a variant of institutional bonding that suggests cross-sectional variation in IIC reporting based on the reputational benefits of an IPO listing. Siegel argues that when regulatory stringencies are only weakly enforced, legal bonding is not effective, yet foreign listers can still benefit from cross-listing by building their reputation by self-selecting to make additional disclosures. Thus, whereas the institutional bonding hypothesis framed in legal terms predicts that there may be no difference between CIPO and CRM IIC reporting and under-reporting in the absence 
of rigorous enforcement, firms may be motivated by reputational benefits instead. Because IPOs are more visible and include underwriter certification and exchange screening and scrutiny, firms motivated by reputational bonding will more likely self-select to list via IPO than via reverse merger. Consistent with Jensen's (1993) assertion that the two key forces protecting investors are the institutional environment and a firm's internal control systems, CIPOs can thus be expected to implement more effective internal controls and reporting. By comparison, CRMs that have self-selected a less visible and expedited listing method less conducive to reputational signaling will have less incentive toward strong internal controls and transparent IIC disclosures. Thus, reputational bonding suggests that extant research on CRM financial reporting cannot be generalized to CIPOs, and that CIPOs are likely to both have better internal controls and to be less likely to under-report internal controls.

However, there are also countervailing forces related to China that may influence the listing decision of Chinese firms beyond reputational bonding motivations. Specifically, Chinese firms may have compelling alternative reasons for accessing U.S. capital markets, including China's multiple freezes on IPOs (Li 2013), generally slower IPO processing (Ren 2014), and liquidity constraints encountered in China's capital markets (Thomas and Barreto 2014). CRMs also have unique motivations for reverse merger listings that are not related to internal controls: firms in sensitive industries that use variable interest entity (VIE) structures to circumvent restrictions on foreign ownership may choose a reverse merger to avoid making required IPO disclosures that may draw attention from Chinese regulators wary of "creative compliance" with foreign investment laws (Gillis and Lowry 2014). Thus, whereas reputational bonding predicts lower IIC reporting and under-reporting by CIPOs than by CRMs, China's unique market and regulatory motivations make this an empirical question. We assess potential reputational bonding differences between CIPOs and CRMs in IIC reporting and under-reporting using bi-directional hypotheses $\mathrm{H} 3$ and $\mathrm{H} 4$, respectively, both ceteris paribus.

Hypothesis 3. IIC reporting likelihood differs between CIPOs and CRMs. Hypothesis 4. IIC under-reporting likelihood differs between CIPOs and CRMs. 


\section{METHOD AND MEASURES}

\section{IIC Dependent Variables}

We use 302 and 404(b) disclosures to compare the likelihood of CIPOs, CRMs, and U.S.-domiciled firms to report IICs. This contrasts with a focus in prior research on 404(b) reporting by the reasoning that audited reports provide more credible evidence (e.g., Kim, Song, and Zhang, 2011; Rice and Weber 2012; Rice, Weber, and Biyu, 2015). However, little direct evidence exists regarding whether 404(b) disclosures provide more credible evidence of IICs, ${ }^{11}$ and conversely, Beneish et al. (2008) find information content for only 302 reports in market reaction tests of 302 and 404(b) reports. Our sample timeframe is 20082012, which by design choice follows an initial learning period and release of clarifying implementation guidance in PCAOB Audit Standard No. 5, released in July of 2007, and SEC Commission Guidance Regarding Management's Report on Internal Control over Financial Reporting, released in June of 2007 (PCAOB 2007; SEC 2007). The guidance would likely have been understood and adopted by manager and auditor IIC reporting for 2008.

Examining both 302 and 404(b) disclosures provides several design advantages. First, because 302 reporting is quarterly versus annually for 404(b) reporting, 302 reports provide more timely indicators of IICs. Second, a comparison of 302 and 404(b) reports enables a comparison of management versus auditor reporting, thus helping reveal the effects of auditor influence on IIC under-reporting. Tellingly, studies find that for 302 filers, managers tend to report fewer IICs than auditors, and auditors often override management assessments of IICs (Bedard and Graham 2011; Munsif, Raghunandan, and Rama 2013). Third, given the 2010 Dodd-Frank Act's (Dodd-Frank) provision permanently exempting non-accelerated filers from 404(b) auditor reporting, management reports are the only indicator of IICs for almost half of Chinese U.S.-listed firms. We measure IICs using indicator variables for both 302 and 404(b) disclosures: 302 is an indicator set to " 1 " when there is a report of IICs under SOX 302 provisions by management during any quarter of a

\footnotetext{
${ }^{11}$ In their review of the first decade of SOX research, Coates and Srinivasan (2014) do not mention any studies comparing 302 and 404(b) disclosures.
} 
fiscal year; 404(b) is an indicator set to " 1 " when there is a report of IICs under SOX 404(b) provisions by the auditor during a year.

\section{Tests of IIC Reporting (H1 and H3)}

In our empirical tests, we control for firm characteristics that influence IICs in two ways. First, we use a modified ACK internal control deficiency determinant model. Second, we use a matched control sample of firm-years, with matching procedures as described below.

Modified ACK model. We employ the following ACK model to control for determinants related to IICs (see Appendix 1 for variable definitions and constructions):

$$
\begin{aligned}
302 / 404(b)= & \beta_{0}+\beta_{1} C I P O+\beta_{2} C R M+\beta_{3} \text { USIPO }+\beta_{4} \text { USRM }+\beta_{5} R A N K G R O W T H \\
& +\beta_{6} \text { BUSSEGS }+\beta_{7} \text { FOREIGNSALES }+\beta_{8} \text { RESTRUCTURE }+\beta_{9} M \& A \\
& +\beta_{10} \text { BIG } 4 A U D+\beta_{11} I N V E N T O R Y+\beta_{12} L N A S S E T S+\beta_{13} R A N K Z \\
& +\beta_{14} L O S S+\varepsilon
\end{aligned}
$$

Significant and positive $\beta_{1}$ and $\beta_{2}$ coefficients indicate a higher likelihood of reporting IICs (H1). We assess IIC reporting differences between CIPOs and CRMs (H3) by testing whether $\beta_{1}$ equals $\beta_{2}$ in equation (1) above. We deviate slightly from ACK's model 1 to reflect our research focus on the IICs of Chinese U.S.listed firms. Specifically, we add CIPO and CRM indicators and test for a significantly positive $\beta_{1}$ on $C I P O$ and $\beta_{2}$ on CRM to test hypothesis H1. Our measures of CIPO, CRM, USIPO, and USRM are indicators of listing since 2000, and control for a recent listing effect, reflecting prior evidence that firms that list by IPO tend to differ from those that list by reverse merger (Adjei, Cyree, and Walker 2008; Gleason, Rosenthal, and Wiggins III 2005). ACK employ data from three consecutive firm-years for the GROWTH, RESTRUCTURE, M\&A, and LOSS measures; to lessen the resulting loss of firm-years, we employ oneyear measures (with qualitatively similar findings for three-year measures as in ACK). We omit ACK's measure of prior year auditor resignation because, in our setting, a large proportion of CIPO and CRM firmyears contain auditor changes commensurate with going public and/or a U.S. listing (Coates and Srinivasan 
$2014)^{12}$. We add BIG4AUD to the ACK model to control for the effects of auditor quality on IICs. Because IICs may be concentrated in industries and on exchanges that may be correlated with our Chinese firm sample, we control for industry and exchange fixed effects. To mitigate the effect of outliers, we winsorize the top and bottom one percent of all continuous variables.

Matched regression. In addition to the ACK model, we employ a matching algorithm to further control for other determinants of IICs. Our algorithm matches each Chinese firm-year with a U.S.-listed domestic firm-year with the same year, listing exchange (NYSE/AMEX, NASDAQ, OTC, pink sheets), industry (Fama-French 48), and then nearest total assets,,$^{13}$ without replacement, similar to Lang, Lins, and Miller (2003); Lee et al. (2015) and Chen et al. (2016). We match on exchange because exchange is an endogenous choice that can capture unobservable characteristics such as motivation to avoid listing requirements (in the case of a lower quality exchange), or the desire for visibility or liquidity (in the case of a higher quality exchange) (Baker and Johnson 1990; Corwin and Harris 2001). For example, Choi, Kim, Liu, and Simunic (2009) find that audit quality for cross-listed firms (proxied by audit fee premium) was incrementally higher for those listed on a major exchange, and Shi, Magnan, and Kim (2012) find crosslisters on major exchanges to be more likely to issue management earnings forecasts. We match by industry because firm characteristics, such as fraud incidence (Beasley, Carcello, Hermanson, and Lapides 2000), can vary by industry.

\section{Tests of IIC Under-reporting (H2 and H4)}

Past measures of IIC under-reporting include restatements (Rice and Weber 2012; Mao and Ettredge 2016), patterns of reporting (Kim et al. 2011) and predicting IICs using a discriminant model (Gong et al. 2013). The use of restatements in our setting is problematic, as indicated by Srinivasan et al.

\footnotetext{
${ }^{12}$ Correspondingly, an internal control weakness determinant model by Doyle, Ge, and McVay (2007a), contemporary to ACK, does not include auditor changes in its model.

${ }^{13}$ The matching algorithm is performed on the 302 filer and 404(b) populations separately. We match by total assets rather than market value of equity given evidence that foreign reverse mergers are discounted (Givoly et al. 2014), and that the spillover effects of alleged accounting scandals to nonaccused Chinese U.S.-listed firms were broad (Ang et al. 2014; Darrough et al. 2015) and persists at least a year (Darrough et al. 2015). We perform a robustness check with qualitatively similar but somewhat weaker results, commensurate with market value of equity providing generally smaller U.S.-domiciled matches.
} 
(2014), who find that U.S.-listed foreign firms are less likely to restate earnings, particularly when they are from weak legal environments. Under-reporting measures based on reporting patterns can be confounded by underlying IIC incidence. For example, a higher (lower) percentage of firms exhibiting years in which 404(b) IICs are preceded by no 302 IICs may simply be due to a higher (lower) incidence of underlying IICs for the subgroup, which mechanically makes this condition more (less) likely, rather than due to management reporting choices. For these reasons, we follow Gong et al. (2013), which investigates IIC reporting by cross-listed firms in two stages. In a first stage, they predict IIC using the coefficients from ACK's estimation. In a second stage, they test for significant effects of ownership structure and institutional environment on predicted IIC reporting. In our first stage, we similarly model the likelihood of having IICs by converting equation (1) into a determinant model by eliminating the variables of interest. ${ }^{14}$ Equation (2) is similar to ACK's internal control discovery model (their model 1). We also add exchange fixed effects to control for firm characteristics related to exchange:

$$
\begin{aligned}
302 / 404(b)= & \beta_{0}+\beta_{1} \text { GROWTH }+\beta_{2} \text { BUSSEGS }+\beta_{3} M \& A+\beta_{4} \text { RESTRUCTURE } \\
& +\beta_{5} \text { BIG4AUD }+\beta_{6} L N A S S E T S+\beta_{7} R A N K Z+\beta_{8} L O S S+\varepsilon
\end{aligned}
$$

Estimating equation (2) for our full sample of 302 and our subsample of 404(b) firm-years, we predict the likelihood of an IIC report for each firm (UNDERREPORT_IIC). We then apply a second-stage ordinary least squares regression of UNDERREPORT_IIC on incentives to disclose IICs. We estimate this second stage on the subset of firms that did not report an IIC (i.e., 302/404(b) is equal to zero) since we are interested only in firms that under-report. ${ }^{15}$ The second-stage model thereby tests for differential under-

\footnotetext{
${ }^{14}$ We do not use ACK's coefficients as in Gong et al. (2013) because ACK's estimation is for a time period immediately after the passage of SOX during a time of adoption experimentation. Gong et al.'s study is similarly during the period of initial SOX adoption. Because our setting follows the initial adoption period of SOX as a design feature, including the issuance of clarifying guidance (PCAOB 2007), adoption of ACK's coefficients would be inappropriate. Therefore, we run our ACK-based first stage model to obtain PREDICTED_IIC.

${ }^{15}$ Gong et al. (2013) construct a misreport measure (ICD_MISREPORT) that includes both under- and over-reporting states of ineffective internal controls (they term internal disclosure controls ICDs). In our notation, their ICD_MISREPORT is equal to UNDERREPORT_IIC minus 302/404(b). Their ICD_MISREPORT has a bimodal distribution that ranges between -1 to +1 , and they run their analysis with their full sample. Because our treatment firms have dramatically higher likelihood of reporting IICs, in our setting, the construction of Gong et al.'s (2013) ICD_MISREPORT measure would generate a significantly more negative ICD_MISREPORT measure due to disproportionate Chinese-firm clustering in the first peak of the bimodal distribution (302/404(b) equal to 1). Therefore, employing their ICD_MISREPORT measure on our whole population would confound our ability to
} 
reporting of only a subset of our treatment firm-years with clean IIC reports, while controlling for other incentives to disclose IICs. Testing hypothesis $\mathrm{H} 2$ takes the following form:

$$
\begin{aligned}
\text { UNDERREPORT_IIC }= & \beta_{0}+\beta_{1} C I P O+\beta_{2} C R M+\beta_{3} U S I P O+\beta_{4} U S R M+\beta_{5} B I G 4 A U D+\beta_{6} D E B T \\
& +\beta_{7} S E O+\beta_{8} R O A+\beta_{9} L I T I G A T I O N+\varepsilon
\end{aligned}
$$

A significant and positive $\beta_{1}$ and $\beta_{2}$ would support hypothesis H2 for CIPOs and CRMs, respectively. We assess differential CIPO and CRM under-reporting (H4) by testing whether $\beta_{1}$ equals $\beta_{2}$ in our estimates of equation (3). ACK include four measures to model IIC disclosure incentives: we retain their controls for BIG4AUD and LITIGATION, but omit concentration of institutional ownership and restatements for three reasons. First, concerns regarding these measures as reviewed by Leone (2007); second, to avoid possible differences in institutional ownership among foreign listers; and third, in view of Srinivasan et al.'s (2014) finding of opportunistic under-restating by foreign listers. We also control for firm performance $(R O A)$ and add indicators of future year debt issuance and seasoned equity offerings (DEBT and SEO) to control for incentives to disclose IICs. ${ }^{16}$

\section{SAMPLE SELECTION AND DESCRIPTIVE STATISTICS}

\section{Sample Selection}

Our treatment sample of Chinese U.S.-listed firms is comprised of those that first listed in the U.S. either by IPO or by reverse merger during the period 2000-2012. Table 1 summarizes sample firm identification and data collection sources, and resultant firm-year sample sizes, and details of our sample construction are provided in Appendix Sample selection.

\footnotetext{
$* * * * * * *$ Table 1 about here $* * * * * * *$
}

investigate under-reporting. Since our under-reporting research question involves the second peak of the ICD_MISREPORT distribution $(302 / 404(b)$ equal to 0 ), we investigate only potential under-reporters (where 302/404(b) equal to 0 ).

${ }^{16}$ Our results are not sensitive to the inclusion of these additional control variables. 
We collected requisite firm-year data from Compustat and Audit Analytics for the years 20082012. We did not include firm-years prior to 2008 due to the regulatory clarification process from the time of SOX adoption through the PCAOB's Audit Standard No. 5 at the end of 2007 (Coates and Srinivasan 2014). Further, we excluded firm-years with less than $\$ 20$ million in revenues, firms in financial industries (SIC codes 6000-6999), and the twelve dual-listed firms. Our findings are not sensitive to these selection criteria (see robustness checks in Section 6). Panel B of Table 1 presents our resulting 302 filer sample, which is comprised of 374 firm-years for 111 CIPOs and 448 firm-years for 144 CRMs between 20082012, inclusive. The sampling procedure substantially reduces the number of USRM observations due to variable requirements (by 42 percent) and minimum revenue size $\$ 20$ million (by 52 percent), which documents fundamental differences between USRMs and CRMs that reinterpret prior findings that use USRMs as a control group (Lee et al. 2015; Mao and Ettredge 2016). Control firms are U.S.-domiciled U.S.-listed firms with available data in the Compustat and Audit Analytics databases. Our 404(b) filer sample, a subsample of the 302 filer sample, is presented in panel $\mathrm{C}$ and shows a reduced sample across the board, but notably, the CRM sample has the largest reduction.

\section{Descriptive Statistics}

Descriptive statistics are provided in Table 2 for Chinese and U.S.-domiciled firm-years. Panel A contains descriptive statistics and univariate tests ${ }^{17}$ of differences for our sample of 302 filer firm-years. The 33.8 percent incidence of 302 IIC disclosures in the Chinese sample is four times the incidence for U.S. domestic 302 filers $(p<0.01)$. Chinese firms also exhibit significantly higher revenue growth, fewer business segments, lower inventory and less foreign income, fewer merger and acquisition and restructuring activities, as well as fewer prior-year losses and higher Altman (1968) Z-scores (where bankruptcy risk is lower as Z-score rises). Only 45.6 percent of Chinese U.S.-listed firms use Big-4 auditors compared with 73.9 percent for U.S.-domiciled firms $(p<0.01)$.

\footnotetext{
${ }^{17}$ For continuous variables, we perform $t$-tests; for indicator variables, we provide chi-square statistics. We also perform the nonparametric Wilcoxon rank-sum test (untabulated) which shows no difference to the t-tests in significance, except the Wilcoxon test significance level for BUSSEGS is $p<0.05$ and $p<0.10$ for panels B and C, respectively.
} 
Descriptive statistics and univariate tests for the 404(b) filer subsample are provided in panel B (Table 2). The Chinese and U.S. firm-year observations decline by 52 and 20 percent, respectively, thus corroborating our design choice to examine both 302 and 404(b) disclosures. Among 404(b) filers, the Chinese U.S.-listed firm-year incidence of 404(b) IIC disclosures is five times that for domestic U.S.-listed firm-years, a higher magnitude than the fourfold Chinese firm-year incidence of 302 IIC disclosures over its U.S. counterpart incidence in panel A. In general, the difference in the levels of control variables between the Chinese firm-years and U.S. firm-years remain generally significant.

In panel C (Table 2), we compare CIPOs and CRMs. The incidence of CRM 302 IIC disclosures is three times that of CIPOs $(p<0.01)$, providing univariate support for H3. Our sample CIPO firm-years are on average more than eight times the size of CRMs when measured by $M V E$, but the magnitude of this difference is reduced when measured by total assets (both $p<0.01$ ). Compared with CRMs, CIPOs have fewer business segments, less inventory, and higher incidences of $M \& A$ and RESTRUCTURE. RANKZ and GROWTH are not significantly different between the two groups. Importantly, 90 percent of CIPO firmyears have Big-4 auditors, compared to only 9 percent for CRMs.

Pearson correlations for the 302 and 404(b) filer populations (untabulated ${ }^{18}$ ) show that there is no significant multicollinearity. In summary, the univariate tests in Table 2 indicate that Chinese U.S.-listed firms are more likely to report IICs (H1) and differ significantly in other regards from U.S.-domiciled firms. Further evident are within-group differences by listing method between CIPOs and CRMs, both in IIC reports (H3) and in firm characteristics. We examine IIC disclosures while controlling for differences in firm characteristics in the following section.

$* * * * *$ Table 2 about here $* * * * *$

\footnotetext{
${ }^{18}$ All untabulated tests are available from the authors upon request.
} 


\section{MAIN RESULTS}

\section{Ineffective Internal Control Differences (H1 and H3)}

We present tests of hypothesis $\mathrm{H} 1$ and $\mathrm{H} 3$ in Table 3 by estimating equation (1) with the full sample of 302 filers and 404(b) filers in columns (1)-(3), and with matched samples of 302 filers and 404(b) filers in columns (4)-(6). The dependent variable is 302 for our entire sample in column (1) and is 302 and 404(b) for the 404(b) filer subsample in columns (2) and (3), respectively. In Table 3 onward, by design, the degree of auditor influence on the IIC reporting generally increases from left to right, columns (1)-(3). Because column (1) includes all 302 filers, both accelerated 404(b) filers and non-accelerated filers not subject to 404(b) auditor attestation, its IIC reports are more likely to reflect management assessments of IICs. Column (2) reflects more auditor influence over IICs than column (1) because, for these 404(b) filers, their 302 assessments are subject to auditor review at fiscal year-end. Column (3) reflects the highest auditor influence since the dependent variable is auditor 404(b) IIC attestation.

For hypothesis $\mathrm{H} 1$, Table 3 reveals positive coefficients for $C I P O$ in all columns, and statistical significance $(p<0.01)$ for columns $(1)$ and $(3)^{19}$, thereby indicating that CIPO firms have a higher likelihood to report IICs than their U.S. domiciled counterparts, after controlling for determinants of IICs. In columns (4)-(6), we present matched sample tests that help control for latent omitted variables, including those related to the self-selection of an exchange..$^{20}$ Despite a smaller sample size, these results are similar to and sometimes larger than columns (1)-(3); the coefficients on CIPO monotonically increase in the matched sample (columns (4) to (6)). The likelihood of CIPOs to report IICs increases in the matched sample for 404(b); the odds ratio for CIPO for 404(b) reporting for the full and matched samples are 2.45

\footnotetext{
${ }^{19}$ Tests in columns 2 and 5 tend to be weaker, perhaps because of a nexus of two conditions: first, they are on a population with larger firms, suggesting lower underlying IIC propensities, than in columns (1) and (4); second, columns (2) and (5) have a dependent variable with less auditor influence than columns (3) and (6). We have uncovered no other alternative explanations.

${ }^{20}$ We do not employ a Heckman's self-selection model because the selection model for choosing listing by reverse merger, constructed by Adjei et al. (2008) is likely to be different for Chinese firms and relies heavily on reported financials, the integrity of which is at the heart of our research questions. In our setting, a matched sample is an appropriate method to control for observable characteristics that may influence the listing choice and avenue.
} 
and 5.06, respectively ${ }^{21}$. Thus, CIPOs are twice to five times more likely than U.S.-domiciled U.S.-listed firms to make 404(b) IIC disclosures. The coefficients on CRM are all significantly positive and monotonically increase from columns (1) to (3), (and (4) to (6) for the matched sample), suggesting higher IIC reporting as auditor influence on those reports strengthens.

Control variables generally agree with ACK in terms of direction and significance, with the exception of RESTRUCTURE and M\&A. Two likely reasons for these differences are: First, ACK's setting is in the first year of SOX 302 implementation and thus may reflect unfamiliarity with its requirements and the internal controls it assesses. Second, ACK's dependent variable was the less severe "IC deficiency" report. By comparison, our dependent variable is management's overall report of IICs, and our setting is 2008-2012, which by design choice follows an initial learning period and release of clarifying implementation guidance by the PCAOB and the SEC in the summer of 2007, and should have been understood and adopted by manager and auditor IIC reporting for 2008 (PCAOB 2007; SEC 2007). BIG4AUD is generally negative (significant for the full sample of 302 firm-years), in line with prior research indicating that Big-4 auditors incentivize client firms to implement stronger internal controls. A formal test of difference in coefficients for CIPO and CRM is also highly significant $(p<0.01)$ in all columns, thereby lending support to $\mathrm{H} 3$.

Overall, the results in Table 3 indicate that CIPOs, as well as CRMs, are more likely to report IICs than U.S.-domiciled U.S.-listed firms (H1), and CIPOs are less likely to report IICs than CRMs (H3). Table 3 also provides suggestive evidence of under-reporting, in that coefficients for $C I P O$ and $C R M$ are higher when 404(b) (versus 302) is the dependent variable, suggesting increased IIC reporting as the auditor role in IIC reporting increases. Another implication of Table 3's evidence that CIPOs have higher IIC propensities than U.S. domiciled counterparts is that CIPOs are not an appropriate control group for testing CRM financial reporting quality (e.g., Chen et al. 2016; Mao and Ettredge 2016).

\footnotetext{
${ }^{21}$ These odds ratios are consistent with the univariate measures of CIPO IIC propensities in Table 2 and Addendum 1 panel A.
} 
$* * * * *$ Table 3 about here $* * * * *$

\section{Under-reporting of IICs (H2 and H4)}

We next provide evidence on whether Chinese U.S.-listed firms are more likely to under-report IICs than U.S.-domiciled U.S.-listed counterparts. Table 4 presents results for tests of IIC under-reporting (H2 and H4) using a two-stage regression for our matched sample, and findings are qualitatively similar for the unmatched dataset. In the first stage estimation (untabulated), the results for matched firms exhibit substantively similar signs and significance as in Table 3, except BIG4AUD becomes consistently significantly negative $(p<0.01)^{22}$. Table 4 presents the results of the second-stage regressions, using the predicted IICs from the first stage as the dependent variable in estimations of equation (3) with the subsample of matched firms with clean IIC reports. Thus, the intercepts represent the average PREDICTED_IIC. Hypothesis $\mathrm{H} 2$ predicts positive coefficients on CIPO and CRM; estimates in columns (1)-(3) reveal that in the matched sample of 302 filers, CIPOs under-report 302 IICs $(p<0.01)$. CRM is positive and statistically significant in all three columns. Overall, the results in Table 4 lend support to H2.

For H4 tests of differential under-reporting by CIPOs and CRMs, results differ for 302 and 404(b) filers. For 302 filers, the magnitude of the under-reporting is not significantly different between CIPOs and CRMs; however, for the 404(b) filers, the coefficient for CIPO is significantly less than CRM, thereby supporting H4. Table 4 also helps confirm that the findings in Table 3 are not due to over-reporting. In untabulated results, we find further that under-reporting is not isolated within years before the heightened scrutiny period (2010-2012); rather, under-reporting is statistically significant in the scrutiny period despite the heightened attention. BIGAAUD is also significantly negative with a Big-4 auditor reducing PREDICTED_IIC by 12 to 20 percent on average, which we consider in the supplementary analysis section.

\footnotetext{
${ }^{22}$ Our likelihood ratios and Wald statistics for the first-stage compare favorably with ACK. Although pseudo-R-square statistics exist for logistic regression, they are not adequate measures model fit (Hosmer, Lemeshow, and Sturdivant 2013). Our pseudo-Rsquares are equal or higher than those in other studies that use a prediction from a determinant model for a second-stage analysis (see for example Campa and Kedia (2002); Masulis, Wang, and Xie (2012); Fang, Maffett, and Zhang (2015)).
} 
The under-reporting of IICs by both CIPOs (for the 302 filer matched sample) and CRMs and the insignificant difference between their under-reporting for 302 disclosures may help explain why investors and regulators failed to distinguish "good apples" from "bad apples", their resulting high stock price synchronicity, and remedial regulatory actions that failed to distinguish between them (Ang et al. 2014; Darrough et al. 2015)

$* * * * * * *$ Table 4 about here $* * * * * * *$

\section{The Effect of Scrutiny on IIC Reporting}

We next examine as a corroborative test of $\mathrm{H} 1$ and $\mathrm{H} 2$ the effect of heightened media and regulatory scrutiny of Chinese U.S.-listed firms in 2010-2012. Notwithstanding possible perceptions of low enforcement risk among Chinese U.S. listers, prior findings indicate public scrutiny promotes corporate governance and disclosure (Abrahamson and Park 1994; Yue, Richardson, and Thornton 1997; Bednar, Boivie, and Prince 2013). Particularly relevant to this study is Rice and Weber (2012), who investigate 404(b) reporting for a set of firms with restatements related to internal control material weaknesses (hereafter, ICMWs), which are reported as part of the internal control audit. Rice et al. find that firms with prior accounting problems or poor financial health are more likely to report 404(b) ICMWs, which they interpret as increased reporting by a subset of firms subjected to additional scrutiny, but they do not separately examine Chinese U.S.-listed firms.

Chinese U.S.-listed firms experienced higher scrutiny starting the summer of 2010. On June 28, 2010, Muddy Waters released the first of several reports on Orient Paper Inc. (NYSE ONP), with a strong sell recommendation warning of significant revenue and asset overstatement and misappropriation of raised capital (Block and Regan 2010). Within weeks, the PCAOB signaled its concerns regarding Chinese U.S.listed firms in a Staff Audit Practice Alert, leading to a wave of 60 fraud allegations for CRMs ${ }^{23}$ and further regulatory scrutiny (PCAOB 2011; SEC 2011). The advent of intense scrutiny of the financial reporting

\footnotetext{
${ }^{23}$ As identified by Darrough et al. (2015), comprised of CRMs subject to SEC enforcement actions, class-action lawsuits, or mediareported fraud allegations.
} 
practices of Chinese U.S.-listed firms by the media and regulators for the period 2010-2012 provides a unique intervention, facilitated by comparisons of SOX 302 and 404(b) disclosures, to apply difference-indifference comparisons to address whether heightened scrutiny is an alternative explanation for test results for $\mathrm{H} 1$ in Table 3. Differential reporting pre- and post- scrutiny can also provide insight regarding underreporting results for H2. Following Darrough et al. (2015), who test for stock market spillover effects among Chinese U.S. listers during this increased scrutiny period, we add to equation (1) a SCRUTINY indicator for the years 2010-2012 and its interaction with $C I P O$ and $C R M$ :

$$
\begin{aligned}
302 / 404(b)= & \beta_{0}+\beta_{1} C I P O+\beta_{2} \text { CRM }+\beta_{3} \text { USIPO }+\beta_{4} \text { USRM }+\beta_{5} \text { GROWTH }+\beta_{6} \text { BUSSEGS } \\
& +\beta_{7} M \& A+\beta_{8} \text { RESTRUCTURE }+\beta_{9} \text { BIG } 4 A U D+\beta_{10} \text { LNASSETS }+\beta_{11} \text { RANKZ } \\
& +\beta_{12} \text { LOSS }+\beta_{13} \text { SCRUTINY }+\beta_{14} \text { CIPOxSCRUTINY } \\
& +\beta_{15} \text { CRMxSCRUTINY }+\varepsilon
\end{aligned}
$$

Results are presented in Table 5. If the interaction term CIPOxSCRUTINY from equation (4) is positive and statistically significant, for 302 and 404(b), this indicates either more truthful reporting in later years or over-reporting in later years. In column (1), the CIPOxSCRUTINY coefficient is significant and positive $(p<0.05)$ while CIPO is insignificant. In column (3), with $404(b)$ as the dependent variable, the interaction is no longer significant, and CIPO is positive and significant $(p<0.01)$. CRMxSCRUTINY shows a decreasing pattern from columns (1) to (3), with the scrutiny effect being strongest in 302 reports for 302 filer population $(p<0.01)$, and both significance and coefficient size dropping from columns (1) to (3). The coefficient on $C R M$ is positive and significant (all $p<0.01$ ), and monotonically increasing from column (1) to (3). Taken together, the regressions reported in Table 5 provide evidence that the managements of both CIPOs and CRMs responded to regulatory and media scrutiny by reporting more IICs; whereas there is no significant effect for CIPO 404(b) auditor attestation, CRM 404(b) IIC reports also increased during the scrutiny period. These results are not consistent with an over-reporting explanation for our findings in Table 3; rather, they are consistent with CIPO managers and CRM managers and auditors under-reporting IICs before 2010 when there was less scrutiny. The negative, significant coefficient on SCRUTINY is 
consistent with a general time-trend of reduced IIC reporting for all filers (Ye, Hermanson, and Krishnan 2013).

$* * * * * * *$ Table 5 about here $* * * * * * *$

Thus, results in Tables 4 and 5 for the scrutiny period serve to corroborate prior evidence that Chinese U.S.-listed firms under-report IICs, particularly 302 IICs and CRMs. The 302 under-reporting indicated in Tables 4 and 5 further suggests that the 404(b) exemption may have led to less diligent financial reporting, at least for Chinese U.S. listers.

\section{SUPPLEMENTARY ANALYSIS}

\section{Chinese U.S.-listed Firm Auditors}

We next provide corroborative descriptive evidence comparing CIPO and CRM auditors. Table 6 presents the signing auditors' engagement frequencies and total fees of Chinese U.S.-listed firms during our study period. In panel A, the Big 4 (in bold) dominate the CIPO audit market, accounting for 90 percent of the engagements and 98 percent of the fees in our sample. In panel B, CRM auditors and fees differ starkly, as only 9 percent of CRMs have Big-4 auditors, and Ernst \& Young LLP and PricewaterhouseCoopers LLC rank below the top-15 CRM auditors by the number of engagements. Big4 auditors represent 26 percent of CRM fees, consistent with auditing more complex and/or larger CRM clients. This evidence of Big-4 audit differences between CIPOs and CRMs is consistent with prior findings that Big-4 auditors are associated with stronger internal controls ${ }^{24}$ and of lower IIC reporting and underreporting for CIPOs versus CRMs.

$* * * * * * *$ Table 6 about here $* * * * * * *$

\footnotetext{
${ }^{24}$ We thank a reviewer for pointing out that our findings do not address the direction of causality; it is possible that Big 4 auditors choose clients with strong internal controls.
} 


\section{Internal Control Material Weakness Types}

In untabulated results, we further examine differences in ICMW types. When an IIC is reported, management or the auditor (for 302 and 404(b), respectively) is required to disclose what material weakness(es) triggered the filing (SEC 2003), which are codified into over 80 discrete types by AuditAnalytics $^{\mathrm{TM}}$. Univariate tests of differences between CIPOs, CRMs and their matched U.S. counterparts reveal significant differences between CIPOs, CRMs, and their matched U.S. domestic counterparts. In particular, a strong tendency is indicated for Chinese U.S.-listed firms to report ICMW types that relate to general financial reporting quality (codes 40,50, and 68) and personnel and segregation of duties (code 51) for both CIPO and CRMs. Prior research shows that such company-level ICMWs are associated with less remediation (Johnstone, Li, and Rupley 2011), lower accruals quality (Doyle et al. 2007b) and more negative stock market reactions (Hammersley, Myers, and Shakespeare 2008). Consistent with our findings for H3, CRMs report more types of ICMW than CIPOs - notably, accounts receivable issues (code 15) and related party issues (code 38), both of which suggest tunneling via related parties. ${ }^{25}$ Importantly, revenue recognition issues are not significantly different between Chinese firms and their U.S. matched counterparts in 302 or 404(b) ICMWs, suggesting that classical earnings management problems may not be a dominant financial reporting issue among Chinese U.S.-listed firms compared with U.S.domiciled counterparts, and that internal controls may serve as an apt and more applicable measure of financial reporting quality for Chinese U.S.-listed firms than accrual-based measures. CIPOs have significantly fewer restatements amongst both 302 and 404(b) filers, and the percentage of CRMs restating is nominally higher but not statistically significant. The significantly higher ICMWs coupled with the significantly lower restatements for CIPOs suggest that restatements may not be an appropriate measure to capture under-reporting of IICs as used in Mao and Ettredge (2016).

\footnotetext{
${ }^{25}$ These additional codes become insignificant for the 404(b) population, which is likely a combination of the association between internal control weakness and firm size, and the reduction in sample size. Tests on all ICMW types between CIPOs, CRMs, and their matched counterparts are available from the authors on request.
} 


\section{Robustness Checks}

To ensure that our results are robust to sample selection, measurement, and estimation choices, we perform several sensitivity checks. When we reduce the required minimum revenue from $\$ 20$ million to \$10 and \$1 million, include dual-listed Chinese firms and other omitted Chinese firm observations (as detailed in Table 1), and omit firms trading OTC and on pink sheets, our results are qualitatively similar. CIPO becomes significant in Table 4 in all columns when we examine only firms on major exchanges.

Our results also are not sensitive to our implementation of the ACK discovery model in three regards. First, our findings are similar when we use three-year measures as in ACK, even though the sample size is reduced. Second, our results are not sensitive to the use of alternative measures for ACK controls, such as if we dichotomize $M \& A$ and RESTRUCTURE equal to 1 if greater than 1 or 5 percent of total assets. Third, ACK do not include a Big-4 auditor measure in their discovery model. Although we assert that $B I G 4 A U D$ may affect both the discovery of IICs and their under-reporting, our results are qualitatively unchanged when we remove BIG4AUD from our discovery models (equations (1)-(3)).

As noted in Section 3, we perform an alternate match using $M V E$ for size and find slightly attenuated but qualitatively similar results. For our under-reporting analysis, we have listing controls in the second stage. When we include them in the first stage, the results are also substantively similar. When we estimate the under-reporting analysis on the full sample of 302 and subsample of 404(b) firm-years, the results are qualitatively similar, except $C I P O$ becomes significant for the regressions for 404(b) filers. While clustering standard errors is contraindicated for logistic regression, as a further check, we perform a linear probability model, clustering by firm (and by firm-year) and the results are consistent with our tabulated logistic regressions.

\section{DISCUSSION AND SUMMARY}

Chinese firms listing their shares in U.S. via "back door" reverse mergers (CRMs) have dominated prior media, regulator and research attention amid charges of financial reporting weaknesses. Yet CRMs 
have effectively ceased, leaving Chinese firms listing via IPOs (CIPOs) as the relevant remaining class of Chinese firms listing on U.S. stock exchanges. Because CIPOs are generally larger and subject to stricter scrutiny in their listings, problems plaguing CRM financial reporting may not generalize to this "front door" class of firms. Yet little prior evidence exists regarding the internal controls underlying the financial reporting quality of CIPOs. This study addresses this gap by examining both SOX Section 302 and 404(b) ineffective internal control reports and related disclosures to compare CIPOs with CRMs and domestic U.S.-listed firms, with three main sets of findings. First, both CIPOs and CRMs have a higher propensity to report IICs than U.S.-domiciled counterparts. Second, both CIPOs and CRMs are more likely to underreport IICs than U.S.-domiciled counterparts, with only CIPOs having higher under-reporting propensities for 302 disclosures consistent with enhanced oversight by their auditors for 404(b) disclosures. Third and importantly, CIPOs are both less likely to report and less likely to under-report IICs than CRMs. These findings document salient differences between CIPOs and CRMs. Additional corroborative evidence of differences between CIPOs and CRMs is provided by their auditors, types of IICs disclosed, and by reporting responses during a period of heightened media and regulatory scrutiny.

These results extend and reinterpret prior research. Specifically, the documented higher likelihood of IIC reporting and under-reporting by CIPOs and CRMs compared with U.S.-domiciled U.S.-listed firms reveal a partial pooling equilibrium wherein it would be difficult for investors to distinguish between firms with strong versus weak financial reporting systems among Chinese U.S.-listed equities. This helps to explain the stock spillover effects observed in Darrough et al. (2015) and help answer Ang et al.'s (2014, 2) question of "Why did US investors and analysts indiscriminately dump all Chinese shares?". This partial pooling also helps explain the survival and uplisting findings of Lee et al. (2015).

Our finding of a higher likelihood of IICs for CIPOs and CRMs also informs interpretations of performance measures such as ROA since the integrity of financial measures relies on internal controls. Our evidence of higher IIC reporting and under-reporting propensities for CRMs, in particular, may help explain Lee et al.'s finding of increasing auditor adverse opinions for CRMs over the three years following their listing. Lee et al. further find CRMs to have fewer adverse audit opinions than USRMs in their first 
year of listing, a difference that weakens and disappears within three years, consistent with IIC weaknesses, and the under-reporting of them by undermining auditors' short-term ability to discern going concern risk. ${ }^{26}$

Our findings also extend the findings of Chen et al. (2016) and Lee et al. by moving the conversation of Chinese U.S.-listed firms beyond CRMs, and highlighting CIPOs as a distinct class of foreign U.S. listers. Chen et al. emphasize the reverse merger listing method as evidence of weak bonding, which they view as a major explanation for CRM financial reporting issues. Whereas we agree that bonding is a likely partial explanation, we also provide evidence supportive of what they call a "China effect", i.e., a broad issue with internal control compliance, consistent with specific cultural influences relevant to the implementation of internal control systems and attendant IIC disclosures. Whereas we identify various aspects of cultural influence, such as in-group versus out-group behavior and lack of advocacy participation, that motivate our findings, we are not able to detect through these tests which cultural influences are tied to ineffective internal controls and their reporting. Given the globalization of capital markets, an understanding of cultural aspects which may impede financial reporting systems is an important direction of future research.

Our findings of higher likelihood of reporting and under-reporting of IICs for both CIPOs and CRMs compared with U.S. domiciled firms, along with ICMW restatement propensities discussed in section 6, reinterpret findings in Mao and Ettredge (2016). While Mao and Ettredge fail to find lower 302 IIC reporting for CRMs before restatements, their test is not specified for testing under-reporting for two reasons. First restatements are a biased measure of weak internal controls in this setting. We find that CRMs have of higher likelihood to report IICs and no higher incidence of restating in our ICMW analysis, suggesting that CRMs are likely to restate less than is warranted. This evidence is consistent with Srinivasan et al.'s (2014) finding of opportunistic under-restating of financials by foreign U.S.-listers, especially from

\footnotetext{
${ }^{26}$ Further, our sample selection highlights a key issue of Lee et al.'s design choice of CRM and USRM comparisons, with 52 percent of USRM firm-years not meeting our $\$ 20$ million revenue threshold. Summary statistics in their Table 2, panel B confirm that CRMs are compared to very small risky USRM firms that differ significantly from CRMs in every control variable prior to their performance comparison period.
} 
weak rule of law countries. Second, CRMs have a three-fold higher likelihood of reporting IICs, making a 302 IIC report mechanically more likely for all CRMs. Both the under-restatements and the higher propensity to have IICs bias against finding a pattern of no 302 report, then a restatement. Thus while it is not surprising that Mao and Ettredge did not find fewer 302 reports for CRMs who restated, these biases in the methodology do not allow their tests to provide evidence against CRM under-reporting internal control issues.

Our findings regarding IIC reporting and under-reporting among 404(b)-exempt filers provides new evidence to the debate regarding the necessity of auditor attestation under 404(b). Whereas Kinney and Shepardson (2011); Dowdell, Herda, and Notbohm (2014) provide evidence consistent with 404(b) not being necessary beyond management IC reports, Holder, Karim, and Robin (2013) find evidence consistent with 404(b) improving financial reporting quality. Our study is focused on Chinese U.S.-listed firms, a class of firms with suspect financial reporting and we find evidence consistent with 404(b) reporting providing a disciplining effect on management reporting on IICs. Further research can help identify other segments of non-accelerated filers who are more succeptible to under-reporting of IICs in the absence of 404(b).

Finally, our findings suggest that a review of the 404(b) exemption for non-accelerated foreign filers is appropriate, as well as continuing regulatory monitoring and enforcement as pledged by the SEC (White 2013; Ceresney 2015). With this in mind, future research can examine ineffective internal controls over financial reporting for other foreign U.S.-listers. Despite an initial inclination for U.S.-listed Chinese firms to de-list or go private in response to U.S. media and regulatory scrutiny in 2010-2012 (Hansen and Öqvist 2013), U.S. IPOs by Chinese firms have rebounded in recent years (Shih 2015). Chinese firms have also increasingly listed on Chinese exchanges via reverse mergers (Ren 2016). Given China's recent stock market history, related regulatory interventions, IPO and foreign listing incentives (Areddy 2015; Chen and Zhang 2017), the financial reporting quality and underlying internal controls Chinese listed firms thus continue to be a priority for regulators, investors, and other market stakeholders globally, including in China. 


\section{Appendix}

Sample selection

Our sample selection first involves identifying IPO and RM events for the period of 2000-2012, removing foreign firms that are not Chinese, and then identifying IPO and RM firms who are reporting for our sample period 2008-2012. Following Lee et al. (2015) and Darrough et al. (2015), our CRM and IPO sample is limited to reverse mergers completed during 2000-2012 for three reasons: First, CRMs were few but increasing before 2004 (Chen et al. 2016; Darrough et al. 2015). Second, PrivateRaise's coverage is incomplete before 2000. Third, the listing method (IPO or reverse merger) effects may not be timeinvariant; that is, the listing effect might fade over time due to survivorship bias and corporate evolution.

CIPO and USIPO firm data for the period 2000-2012 were obtained from the Thomson Reuters SDC IPO database ${ }^{\mathrm{TM}}$, where the primary exchange nation was the U.S. and the domicile nation was China or the U.S., respectively. We use Macquarie Capital Services Chinese dual-listed firm report (Gillis and Lynch 2012) and manually reviewed SEC filings to classify each SDC Chinese IPO (via direct listing or American Deposit Receipts, referring to both methods as IPO) as solely listed in the U.S. (CIPO) or as duallisted elsewhere. This process yielded 12 dual-listed firms and 124 CIPOs.

The CRM sample derives primarily from a search of shell reverse merger transactions in PrivateRaise $^{\mathrm{TM}}$, the most comprehensive vendor of reverse merger data, with comprehensive coverage since 2008 and selective coverage for the period 1999-2007. PrivateRaise's "nation" variable indicates where the majority of the operations were located at the time of the reverse merger. Using this variable, we identified 168 CRMs and 167 USRMs. We use Thomson Reuter's SDC International Merger database $(\mathrm{SDC})^{\mathrm{TM}}$ and a Bloomberg listing of CRMs to ensure a more complete identification; there was a high degree of overlap, but this step further identified 6 and 14 CRMs using SDC and Bloomberg, respectively (Gammeltoft 2011).

As a final step to enhance inclusiveness, we further considered Compustat's LOC code. Because the LOC code is scalar, we manually checked each identified firm's SEC filings to determine if they had Chinese operations during our study period (2008-2012). This final step resulted added five and eleven firms to our CIPO and CRM samples, respectively. 


\section{Appendix (continued)}

\section{Variable definitions}

\section{DEPENDENT VARIABLES}

$302=$ Indicator equal to 1 if a 302 report of IIC is reported in at least one quarter of the year, and 0 otherwise.

404(b) = Indicator equal to 1 if a 404(b) report of IIC is reported, and 0 otherwise.

UNDERREPORT_IIC = Residual of estimated probability of 302/404(b)=1 from equation (5) for firms with $302 / 404(b)=0$.

\section{INDEPENDENT VARIABLES}

CHINA

IPO

$R M$

CIPO

CRM

USIPO

USRM

REV\%CHG

RANKGROWTH

BUSSEGS

FOREIGNSALES

RESTRUCTURE

$M \& A$

BIG4AUD

INVENTORY

LNMARKETVAL

LNASSETS

ALTMANZ

RANKZ

LOSS

DEBT

SEO

$R O A$
$=$ Indicator equal to 1 if a Chinese U.S.-listed firm, and 0 otherwise.

$=$ Indicator equal to 1 if became listed through an initial public offering in 2000 or later, and 0 otherwise.

$=$ Indicator equal to 1 if became listed through a reverse merger in 2000 or later, and 0 otherwise.

$=$ Indicator equal to 1 if a Chinese U.S.-listed firm listed through an initial public offering in 2000 or later, and 0 otherwise.

$=$ Indicator equal to 1 if a Chinese U.S.-listed firm listed through a reverse merger in 2000 or later, and 0 otherwise.

$=$ Indicator equal to 1 if a domestic firm listed through an initial public offering in 2000 or later, and 0 otherwise.

$=$ Indicator equal to 1 if a domestic firm listed through a reverse merger in 2000 or later, and 0 otherwise.

$=$ Percentage change in total revenue from the prior year.

$=$ Decile rank of $R E V \% C H G$.

$=$ Number of total business segments.

$=$ Indicator equal to 1 if the firm reported foreign revenue, and 0 otherwise.

$=$ Indicator equal to 1 if the firm reported restructuring charges, and 0 otherwise.

$=$ Indicator equal to 1 if the firm an acquisition, and 0 otherwise.

$=$ Indicator equal to 1 if the auditor was Deloitte \& Touch LLP, Ernst \& Young LLP, KPMG LLP, or PricewaterhouseCoopers LLP, and 0 otherwise.

$=$ End of year total inventory scaled by the end of year total assets.

$=$ Natural logarithm of the end of year market value of equity.

$=$ Natural logarithm of the end of year total assets.

$=$ Index of bankruptcy risk as defined in Altman (1968).

$=$ Decile rank of ALTMANZ.

$=$ Indicator equal to 1 if the firm reported a negative income, and 0 otherwise.

$=$ Indicator equal to 1 if the firm issued new debt in the next fiscal year, and 0 otherwise.

$=$ Indicator equal to 1 if the firm completed a seasoned equity offering in the next fiscal year, and 0 otherwise (See Cohen and Zarowin (2010) for construction).

$=$ Net income divided by total assets at fiscal year-end. 
$=$ Indicator equal to 1 if in a litigious industry (SIC code within 2833-2836, 3570-3577, 3600-3674, 5200-5961, 7370) and 0 otherwise.

SCRUTINY $=$ Indicator equal to 1 if the fiscal year was 2010 through 2012, and 0 otherwise. 


\section{REFERENCES}

Abrahamson, E., and C. Park. 1994. Concealment of negative organizational outcomes: An agency theory perspective. Academy of Management Journal 37 (5):1302-1334.

Adjei, F., K. Cyree, and M. Walker. 2008. The determinants and survival of reverse mergers vs IPOs. Journal of Economics \& Finance 32 (2):176-194.

Altman, E. I. 1968. Financial ratios, discriminant analysis and the prediction of corporate bankruptcy. Journal of Finance 23 (4):589-609.

Ang, J., Z. Jiang, and C. Wu. 2014. Good apples, bad apples: Sorting among Chinese companies traded in the U.S. Journal of Business Ethics:1-19.

Areddy, J. T. 2015. Chinese companies are trapped in IPO logjam. In The Wall Street Journal: Dow Jones \& Company, Inc.

Ashbaugh-Skaife, H., D. W. Collins, and W. R. Kinney Jr. 2007. The discovery and reporting of internal control deficiencies prior to SOX-mandated audits. Journal of Accounting and Economics 44 (12):166-192.

Ashbaugh-Skaife, H., D. W. Collins, J. W. R. Kinney, and R. LaFond. 2008. The effect of SOX internal control deficiencies and their remediation on accrual quality. The Accounting Review 83 (1):217250 .

Baker, H. K., and M. Johnson. 1990. A survey of management views on exchange listing. Quarterly Journal of Business \& Economics 29 (4):3-20.

Beasley, M. S., J. V. Carcello, D. R. Hermanson, and P. D. Lapides. 2000. Fraudulent financial reporting: Consideration of industry traits and corporate governance mechanisms. Accounting Horizons 14 (4):441-454.

Bedard, J. C., and L. Graham. 2011. Detection and severity classifications of Sarbanes-Oxley Section 404 internal control deficiencies. The Accounting Review 86 (3):825-855.

Bednar, M. K., S. Boivie, and N. R. Prince. 2013. Burr under the saddle: How media coverage influences strategic change. Organization Science 24 (3):910-925.

Beneish, M. D., M. B. Billings, and L. D. Hodder. 2008. Internal control weaknesses and information uncertainty. The Accounting Review 83 (3):665-703.

Block, C. C., and S. Regan. 2010. Muddy Waters Initiating Coverage on ONP - Strong Sell. In Muddy Waters Research: Muddy Waters, LLC, 30.

Campa, J. M., and S. Kedia. 2002. Explaining the diversification discount. The Journal of Finance 57 (4):1731-1762.

Cao, B., and Y. Xie. 2016. China reconsiders the homecoming party. In Bloomberg Businessweek (Asia).

Ceresney, A. 2015. FCPA, disclosure, and internal controls issues arising in the pharmaceutical industry. Paper read at CBI's Pharmaceutical Compliance Congress, March 3, 2015, at Washington D.C.

Chen, K.-C., Q. Cheng, Y. C. Lin, Y.-C. Lin, and X. Xiao. 2016. Financial reporting quality of Chinese reverse merger firms: The reverse merger effect or the China effect? The Accounting Review 91 (5):1363-1390.

Chen, T., and D. Zhang. 2017. China will allow more IPOs to lure capital, regulator says. In Bloomberg.

Choi, J.-H., J.-B. Kim, X. Liu, and D. A. Simunic. 2009. Cross-listing audit fee premiums: Theory and evidence. The Accounting Review 84 (5):1429-1463.

Chow, C. W., F. J. Deng, and J. L. Ho. 2000. The openness of knowledge sharing within organizations: A comparative study of the United States and the People's Republic of China. Journal of Management Accounting Research 12:65-95.

Coates, J. C., and S. Srinivasan. 2014. SOX after ten years: A multidisciplinary review. Accounting Horizons 28 (3):627-671.

Cohen, D. A., and P. Zarowin. 2010. Accrual-based and real earnings management activities around seasoned equity offerings. Journal of Accounting and Economics 50 (1):2-19.

Commons, J. M., and E. I. Goldman. 2014. Between a rock and a hard place: Navigating disclosures to U.S. regulators within the framework of China's State Secrets Law. In The National Law Review. 
Corwin, S. A., and J. H. Harris. 2001. The initial listing decisions of firms that go public. Financial Management 30 (1):35-55.

Cullen, J. B., K. P. Parboteeah, and M. Hoegl. 2004. Cross-national differences in managers' willingness to justify ethically suspect behaviors: A test of institutional anomie theory. Academy of Management Journal 47 (3):411-421.

Darrough, M. N., R. Huang, and S. Zhao. 2015. The spillover effect of fraud allegations against Chinese reverse mergers. Available at SSRN 2545685.

Dowdell, T. D., D. N. Herda, and M. A. Notbohm. 2014. Do management reports on internal control over financial reporting improve financial reporting? Research in Accounting Regulation 26 (1):104109.

Doyle, J., W. Ge, and S. McVay. 2007a. Determinants of weaknesses in internal control over financial reporting. Journal of Accounting and Economics 44 (1-2):193-223.

Doyle, J. T., W. Ge, and S. McVay. 2007b. Accruals quality and internal control over financial reporting. The Accounting Review 82 (5):1141-1170.

Eden, S., and R. Holmes. 2010. SEC probes China stock fraud network. In The Street.

Engel, E., R. M. Hayes, and X. Wang. 2007. The Sarbanes-Oxley Act and firms' going-private decisions. Journal of Accounting and Economics 44 (1-2):116-145.

Ettredge, M., J. Heintz, C. Li, and S. Scholz. 2011. Auditor realignments accompanying implementation of SOX 404 ICFR reporting requirements. Accounting Horizons 25 (1):17-39.

Fang, V. W., M. Maffett, and B. Zhang. 2015. Foreign institutional ownership and the global convergence of financial reporting practices. Journal of Accounting Research 53 (3):593-631.

Farh, J.-L., Z. Chen-Bo, and D. W. Organ. 2004. Organizational citizenship behavior in the People's Republic of China. Organization Science 15 (2):241-253.

Franzel, J. M. 2014. A decade after Sarbanes-Oxley: The need for ongoing vigilance, monitoring, and research. Accounting Horizons 28 (4):917-930.

Gammeltoft, N. 2011. Table of Chinese reverse mergers on U.S. exchanges. In Bloomberg News: Bloomberg.

Gao, G. 2016. Chinese regulator probes six companies in IPO fraud crackdown. In Bloomberg News. New York City: Bloomberg.

Gao, X., J. R. Ritter, and Z. Zhu. 2013. Where have all the IPOs gone? Journal of Financial and Quantitative Analysis 48 (06):1663-1692.

Gillis, P., and M. R. Lowry. 2014. Son of Enron: Investors weigh the risks of Chinese variable interest entities. Journal of Applied Corporate Finance 26 (3):61-66.

Gillis, P., and J. Lynch. 2012. Chinese ADRs - new risk. In Macquarie Capital Securities Ltd.: Macquarie Group Ltd.

Givoly, D., C. Hayn, and B. Lourie. 2014. Importing accounting quality? The case of foreign reverse mergers. Available at SSRN 2183724.

Gleason, K. C., L. Rosenthal, and R. A. Wiggins III. 2005. Backing into being public: An exploratory analysis of reverse takeovers. Journal of Corporate Finance 12 (1):54-79.

Goh, B. W., and D. Li. 2011. Internal controls and conditional conservatism. The Accounting Review 86 (3):975-1005.

Gong, G., B. Ke, and Y. Yu. 2013. Home country investor protection, ownership structure and cross-listed firms' compliance with SOX-mandated internal control deficiency disclosures. Contemporary Accounting Research 30 (4):1490-1523.

Hammersley, J., L. Myers, and C. Shakespeare. 2008. Market reactions to the disclosure of internal control weaknesses and to the characteristics of those weaknesses under section 302 of the Sarbanes Oxley Act of 2002. Review of Accounting Studies 13 (1):141-165.

Hansen, J. Ø., and F. Öqvist. 2013. Why do U.S.-listed Chinese firms go private? Available at SSRN 2186683.

Hennock, M. 2004. 2004: China's coming out party. In BBC News: BBC News. 
Hofstede, G. 2007. Asian management in the 21st century. Asia Pacific Journal of Management 24 (4):411420.

Holder, A. D., K. E. Karim, and A. Robin. 2013. Was Dodd-Frank justified in exempting small firms from Section 404b compliance? Accounting Horizons 27 (1):1-22.

Holmes, R. 2010. Chinese reverse-merger regulation looks flawed. In CNBC Stock Blog.

Hosmer, J. D. W., S. Lemeshow, and R. X. Sturdivant. 2013. Applied Logistic Regression. 3rd ed: John Wiley \& Sons, Inc.

Jensen, M. C. 1993. The modern industrial revolution, exit, and the failure of internal control systems. Journal of Finance 48 (3):831-880.

Johnstone, K., C. Li, and K. H. Rupley. 2011. Changes in corporate governance associated with the revelation of internal control material weaknesses and their subsequent remediation. Contemporary Accounting Research 28 (1):331-383.

Kim, J.-B., B. Y. Song, and L. Zhang. 2011. Internal control weakness and bank loan contracting: Evidence from SOX Section 404 disclosures. The Accounting Review 86 (4):1157-1188.

Kinney, J. W. R., and M. L. Shepardson. 2011. Do control effectiveness disclosures require SOX 404(b) internal control audits? A natural experiment with small U.S. public companies. Journal of Accounting Research 49 (2):413-448.

Lang, M. H., K. V. Lins, and D. P. Miller. 2003. ADRs, analysts, and accuracy: Does cross listing in the United States improve a firm's information environment and increase market value? Journal of Accounting Research 41 (2):317-345.

Lee, C. M., K. K. Li, and R. Zhang. 2015. Shell games: The long term performance of Chinese reverse mergers. The Accounting Review 90 (4):1547-1589.

Leone, A. J. 2007. Factors related to internal control disclosure: A discussion of Ashbaugh, Collins, and Kinney (2007) and Doyle, Ge, and McVay (2007). Journal of Accounting and Economics 44 (12):224-237.

Li, A. 2013. China's IPO market reopens. In The Wall Street Journal: Dow Jones \& Company, Inc.

Mao, J., and M. Ettredge. 2016. Internal control deficiency disclosures among Chinese reverse merger firms. Abacus 52 (3):441-4472.

Masulis, R. W., C. Wang, and F. Xie. 2012. Globalizing the boardroom-The effects of foreign directors on corporate governance and firm performance. Journal of Accounting and Economics 53 (3):527554.

Michaels, D. 2015. SEC deal helps pave way for Chinese companies listing in U.S. In Bloomberg.

Munsif, V., K. Raghunandan, and D. V. Rama. 2013. Early warnings of internal control problems: Additional evidence. AUDITING: A Journal of Practice \& Theory 32 (2):171-188.

Osawa, J., and G. Wei. 2015. As China's market tanks, what becomes of the companies hoping to list? . In The Wall Street Journal: Dow Jones \& Company, Inc.

PCAOB. 2007. An audit of internal control over financial reporting that is integrated with an audit of financial statements and related independence rule and conforming amendments. In Accounting Standard No. 5, edited by Public Company Accounting Oversight Board. Washington, D.C.: PCAOB.

---.2010 . Auditor considerations regarding using the work of other auditors and engaging assistants from outside the firm. In Staff Audit Practice Alert No. 6, edited by Public Company Accounting Oversight Board. Washington, D.C.: PCAOB.

- - - 2011. Audit risks in certain emerging markets. In Staff Audit Practice Alert No. 8, edited by Public Company Accounting Oversight Board. Washington, D.C.: PCAOB.

- - - 2016. Staff questions and answers: Audits of mainland China issuers by registered firms outside of mainland China, edited by Public Company Accounting Oversight Board. Washington, DC: PCAOB.

Peng, M. W., D. Y. L. Wang, and Y. Jiang. 2008. An institution-based view of international business strategy: A focus on emerging economies. Journal of International Business Studies 39 (5):920936. 
Ren, D. 2014. China's listing reform under scrutiny after six firms suspend IPO plans. In South China Morning Post. Hong Kong.

- - - 2016. Backdoor listings may rise after Chinese authorities scrap plans to make IPOs easier. In South China Morning Post. Hong Kong.

Rice, S. C., and D. P. Weber. 2012. How effective is internal control reporting under SOX 404 ? Determinants of the (non-)disclosure of existing material weaknesses. Journal of Accounting Research 50 (3):811-843.

Rice, S. C., D. P. Weber, and B. Wu. 2015. Does SOX 404 have teeth? Consequences of the failure to report existing internal control weaknesses. The Accounting Review 90 (3):1169-1200.

Russolillo, S., and C. Driebusch. 2017. Chinese IPOs in the U.S. are saddling investors with big losses. In The Wall Street Journal: Dow Jones \& Company, Inc.

Salter, S. B., and F. Niswander. 1995. Cultural influence on the development of accounting systems internationally: A test of Gray's (1988) theory. Journal of International Business Studies:379-397.

SEC. 2003. Final Rule: Management's Report on Internal Control Over Financial Reporting and Certification of Disclosure in Exchange Act Periodic Reports. In Release No. 33-8238, edited by Securities and Exchange Commission. Washington, D.C.: SEC.

- - - .2007. Commission Guidance Regarding Management's Report on Internal Control over Financial Reporting Under Section 13(a) or 15(d) of the Securities Exchange Act of 1934, edited by Securities and Exchange Commission. Washington, D.C.: SEC.

- - . 2011. Investor Bulletin: Reverse Mergers. In SEC Office of Investor Education and Advocacy, edited by Securities and Exchange Commission. Washington D.C.: SEC.

Shi, Y., M. Magnan, and J.-B. Kim. 2012. Do countries matter for voluntary disclosure? Evidence from cross-listed firms in the US. Journal of International Business Studies 43 (2):143-165.

Shih, T. H. 2013. Pushing for end to deadlock over China's audit secrets. In South China Morning Post. Hong Kong.

--- . 2015. Chinese IPOs in US overshadow growing market retreat. In South China Morning Post. Hong Kong.

Siegel, J. 2005. Can foreign firms bond themselves effectively by renting U.S. securities laws? Journal of Financial Economics 75 (2):319-359.

Srinivasan, S., A. S. Wahid, and G. Yu. 2014. Admitting mistakes: Home country effect on the reliability of restatement reporting. The Accounting Review 90 (3):1201-1240.

Stephen, C. 2011. China's U.S.-listed stocks are junk. In Market Watch. Hong Kong.

Sternberg, J. 2011. Falling out of love with China. In The Wall Street Journal: Dow Jones \& Company, Inc.

Thomas, D., and E. Barreto. 2014. China firms head for U.S. IPOs, not fussed by accounting flap. In Reuters U.S. Edition: Reuters.com.

Triandis, H. C., R. Bontempo, M. J. Villareal, M. Asai, and N. Lucca. 1988. Individualism and collectivism: Cross-cultural perspectives on self-ingroup relationships. Journal of Personality and Social Psychology 54 (2):323-338.

Tu, Y.-T., S.-Y. Lin, and Y.-Y. Chang. 2011. A cross-cultural comparison by individualism/collectivism among Brazil, Russia, India and China. International Business Research 4 (2):175-182.

Turnipseed, D. L., and A. Rassuli. 2005. Performance perceptions of organizational citizenship behaviours at work: A bi-level study among managers and employees. British Journal of Management 16 (3):231-244.

Dodd-Frank Wall Street Reform and Consumer Protection Act. 111-203. July 21.

USCC. 2005. 2005 Report to Congress, edited by U.S.-China Economic and Security Review Commission. Washington, D.C.: GPO.

Van Dyne, L., and J. A. LePine. 1998. Helping and voice extra-role behaviors: Evidence of construct and predictive validity. Academy of Management Journal 41 (1):108-119. 
Vlastelica, R., and D. Bases. 2011. Special report: Chinese stock scams are the latest U.S. import. In Reuters U.S. Edition. New York: Reuters.

White, M. J. 2013. Remarks at the Securities Enforcement Forum. Paper read at Securities Enforcement Forum, October 9, 2013, at Washington D.C.

Ye, Z., D. R. Hermanson, and J. Krishnan. 2013. Shareholder voting in director elections and initial SOX Section 404 reports. Journal of Accounting, Auditing \& Finance 28 (2):103-127.

$\mathrm{Yu}, \mathrm{X}$. 2016. China to fine-tune back-door listing policies for U.S.-listed companies. In South China Morning Post. Hong Kong.

Yue, L. I., G. D. Richardson, and D. B. Thornton. 1997. Corporate disclosure of environmental liability information: Theory and evidence. Contemporary Accounting Research 14 (3):435-474.

Yuk, P. K., and A. Massoudi. 2013. China's answer to Craigslist surges on US debut. In Financial Times. New York.

Zhang, I. X. 2007. Economic consequences of the Sarbanes-Oxley Act of 2002. Journal of Accounting and Economics 44 (1-2):74-115. 
Table 1 Sample composition

Panel A: Sample firm identification (see Appendix for sample selection details)

DealFlow

\begin{tabular}{cccc}
$\begin{array}{c}\text { Chinese } \\
\text { IPO }\end{array}$ & US IPO & $\begin{array}{c}\text { Chinese } \\
\text { Reverse } \\
\text { Merger }\end{array}$ & $\begin{array}{c}\text { U.S. } \\
\text { Reverse } \\
\text { Merger }\end{array}$ \\
\hline \multirow{3}{*}{124} & & 168 & 167 \\
& 1,190 & 6 & \\
5 & & 14 & \\
& & 11 & 1 \\
\hline
\end{tabular}

Total sample firms identified

129

1,190

199

167

Panel B: 302 filer sample firm-year composition

Compustat firm-years

(2008-2012)

\begin{tabular}{cccccc}
$\begin{array}{c}\text { Chinese } \\
\text { IPO }\end{array}$ & US IPO & $\begin{array}{c}\text { Chinese } \\
\text { Reverse } \\
\text { Merger }\end{array}$ & $\begin{array}{c}\text { U.S. } \\
\text { Reverse } \\
\text { Merger }\end{array}$ & $\begin{array}{c}\text { Other } \\
\text { Available } \\
\text { Firm } \\
\text { Years }\end{array}$ & $\begin{array}{c}\text { Total } \\
\text { Firm } \\
\text { Years }\end{array}$ \\
\hline 459 & 4,229 & 696 & 410 & 28,352 & 34,146
\end{tabular}

Less:

Firm-years with missing

Audit Analytics data

Firm-years with missing

Compustat data

Firm-years with

Revenue $<\$ 20 \mathrm{M}$

Financial firm-years

(SIC code 6000-6999)

Other deleted firm-years ${ }^{26}$

(40)

(29)

$(7,322)$

$(7,538)$

(15)

$(1,130)$

(104)

(143)

$(6,554)$

$(7,946)$

(379)

(101)

(213)

$(3,327)$

$(4,046)$

(151)

(3)

0

(284)

Sample firm-years

0

0

0

0

(112)

(112)

Sample firm-years

374

2,441

448

25

10,753

14,041

Sample firms

with available data

111

692

144

15

3,234

3,607

Panel C: 404(b) filer subsample composition

\begin{tabular}{|c|c|c|c|c|c|c|}
\hline Sample firm-years & 265 & 2,037 & 128 & 8 & 8,596 & 11,034 \\
\hline with available data & 87 & 579 & 52 & 6 & 2,103 & 2,827 \\
\hline
\end{tabular}

26 "Other deleted firm-years" is comprised of 58 Chinese dual-listed firm-years wherein the U.S. listing is not the primary listing, 21 Chinese other firm-years, and firm-years for firms listed in avenues other than NYSE, AMEX, NASDAQ, OTC, or pink sheets. 
Table 2 Descriptive statistics and univariate tests

Panel A: Firm-years for 302 filers

( $\mathrm{n}=822$ Chinese firm-years and 13,219 U.S. firm-years)

\begin{tabular}{|c|c|c|c|c|c|c|c|}
\hline & & $\begin{array}{r}\text { Te } \\
\text { Diff }\end{array}$ & $\begin{array}{l}\text { of } \\
\text { nces }\end{array}$ & & & & \\
\hline & Mean & $\mathrm{T}$ & Chi & Std. dev. & Q1 & Median & Q3 \\
\hline 302 REPORT OF IIC & & & & & & & \\
\hline Chinese firm-years & 0.338 & & $* * *$ & 0.473 & 0.000 & 0.000 & 1.000 \\
\hline U.S.firm-years & 0.083 & & & 0.276 & 0.000 & 0.000 & 0.000 \\
\hline RANKGROWTH & & & & & & & \\
\hline Chinese firm-years & 6.122 & $* * *$ & & 3.245 & 4.000 & 8.000 & 9.000 \\
\hline U.S.firm-years & 4.400 & & & 2.816 & 2.000 & 4.000 & 7.000 \\
\hline BUSSEGS & & & & & & & \\
\hline Chinese firm-years & 1.786 & $* * *$ & & 1.349 & 1.000 & 1.000 & 3.000 \\
\hline U.S.firm-years & 2.042 & & & 1.584 & 1.000 & 1.000 & 3.000 \\
\hline INVENTORY & & & & & & & \\
\hline Chinese firm-years & 0.079 & $* * *$ & & 0.093 & 0.004 & 0.049 & 0.128 \\
\hline U.S.firm-years & 0.112 & & & 0.125 & 0.008 & 0.073 & 0.173 \\
\hline $\mathrm{MVE}^{\mathrm{a}}$ & & & & & & & \\
\hline Chinese firm-years & 554.4 & $* * *$ & & $2,362.7$ & 45.1 & 130.8 & 377.6 \\
\hline U.S.firm-years & $3,291.2$ & & & $9,177.5$ & 117.6 & 504.2 & $1,999.7$ \\
\hline ASSETS $^{a}$ & & & & & & & \\
\hline Chinese firm-years & 450.1 & $* * *$ & & 746.2 & 103.4 & 201.1 & 447.9 \\
\hline U.S.firm-years & $3,605.7$ & & & $9,174.6$ & 153.4 & 557.7 & $2,319.3$ \\
\hline RANKZ & & & & & & & \\
\hline Chinese firm-years & 5.704 & $* * *$ & & 2.426 & 4.000 & 6.000 & 8.000 \\
\hline U.S.firm-years & 5.014 & & & 2.462 & 3.000 & 5.000 & 7.000 \\
\hline FOREIGNSALES & & & & & & & \\
\hline Chinese firm-years & 0.313 & & $* * *$ & 0.464 & 0.000 & 0.000 & 1.000 \\
\hline U.S.firm-years & 0.553 & & & 0.497 & 0.000 & 1.000 & 1.000 \\
\hline RESTRUCTURE & & & & & & & \\
\hline Chinese firm-years & 0.017 & & $* * *$ & 0.129 & 0.000 & 0.000 & 0.000 \\
\hline U.S.firm-years & 0.349 & & & 0.477 & 0.000 & 0.000 & 1.000 \\
\hline M\&A & & & & & & & \\
\hline Chinese firm-years & 0.298 & & $* * *$ & 0.458 & 0.000 & 0.000 & 1.000 \\
\hline U.S.firm-years & 0.398 & & & 0.489 & 0.000 & 0.000 & 1.000 \\
\hline BIG4AUD & & & & & & & \\
\hline Chinese firm-years & 0.456 & & $* * *$ & 0.498 & 0.000 & 0.000 & 1.000 \\
\hline U.S.firm-years & 0.739 & & & 0.439 & 0.000 & 1.000 & 1.000 \\
\hline LOSS & & & & & & & \\
\hline Chinese firm-years & 0.265 & & $* * *$ & 0.442 & 0.000 & 0.000 & 1.000 \\
\hline U.S.firm-years & 0.317 & & & 0.465 & 0.000 & 0.000 & 1.000 \\
\hline
\end{tabular}

Panel B: Firm-years for 404(b) filers

$(n=393$ Chinese firm-years and 10,641, U.S. firm-years)

\begin{tabular}{|c|c|c|c|c|c|c|c|}
\hline & & $\begin{array}{r}T \\
\text { Dif }\end{array}$ & & & & & \\
\hline & Mean & $\mathrm{T}$ & Chi & Std. dev. & Q1 & Median & Q3 \\
\hline 404(b) REPORT OF IIC & & & & & & & \\
\hline Chinese firm-years & 0.188 & & $* * *$ & 0.391 & 0.000 & 0.000 & 0.000 \\
\hline U.S.firm-years & 0.037 & & & 0.188 & 0.000 & 0.000 & 0.000 \\
\hline RANKGROWTH & & & & & & & \\
\hline Chinese firm-years & 6.260 & *** & & 3.095 & 4.000 & 8.000 & 9.000 \\
\hline U.S.firm-years & 4.453 & & & 2.739 & 2.000 & 4.000 & 7.000 \\
\hline BUSSEGS & & & & & & & \\
\hline Chinese firm-years & 1.819 & $* * *$ & & 1.306 & 1.000 & 1.000 & 3.000 \\
\hline U.S.firm-years & 2.109 & & & 1.653 & 1.000 & 1.000 & 3.000 \\
\hline INVENTORY & & & & & & & \\
\hline Chinese firm-years & 0.062 & $* * *$ & & 0.088 & 0.000 & 0.023 & 0.093 \\
\hline U.S.firm-years & 0.101 & & & 0.112 & 0.008 & 0.068 & 0.158 \\
\hline $\mathrm{MVE}^{\mathrm{a}}$ & & & & & & & \\
\hline Chinese firm-years & $1,004.6$ & $* * *$ & & $3,347.0$ & 143.4 & 303.5 & 787.3 \\
\hline U.S.firm-years & $4,260.9$ & & & $11,486.1$ & 259.2 & 791.8 & $2,731.3$ \\
\hline ASSETS $^{a}$ & & & & & & & \\
\hline Chinese firm-years & 734.7 & $* * *$ & & 964.3 & 215.9 & 396.6 & 822.5 \\
\hline U.S.firm-years & $4,521.7$ & & & $10,564.3$ & 300.9 & 890.3 & $3,209.4$ \\
\hline RANKZ & & & & & & & \\
\hline Chinese firm-years & 5.875 & $* * *$ & & 2.402 & 4.000 & 6.000 & 8.000 \\
\hline U.S.firm-years & 5.172 & & & 2.383 & 3.000 & 5.000 & 7.000 \\
\hline FOREIGNSALES & & & & & & & \\
\hline Chinese firm-years & 0.382 & & $* * *$ & 0.486 & 0.000 & 0.000 & 1.000 \\
\hline U.S.firm-years & 0.597 & & & 0.491 & 0.000 & 1.000 & 1.000 \\
\hline RESTRUCTURE & & & & & & & \\
\hline Chinese firm-years & 0.023 & & $* * *$ & 0.150 & 0.000 & 0.000 & 0.000 \\
\hline U.S.firm-years & 0.388 & & & 0.487 & 0.000 & 0.000 & 1.000 \\
\hline M\&A & & & & & & & \\
\hline Chinese firm-years & 0.422 & & & 0.495 & 0.000 & 0.000 & 1.000 \\
\hline U.S.firm-years & 0.443 & & & 0.497 & 0.000 & 0.000 & 1.000 \\
\hline BIG4AUD & & & & & & & \\
\hline Chinese firm-years & 0.751 & & $* * *$ & 0.433 & 1.000 & 1.000 & 1.000 \\
\hline U.S.firm-years & 0.850 & & & 0.357 & 1.000 & 1.000 & 1.000 \\
\hline LOSS & & & & & & & \\
\hline Chinese firm-years & 0.272 & & & 0.446 & 0.000 & 0.000 & 1.000 \\
\hline U.S.firm-years & 0.271 & & & 0.445 & 0.000 & 0.000 & 1.000 \\
\hline
\end{tabular}

aWinsorized, in millions. T and Chi are a $t$-test of difference in means and a chi-square test significance, respectively. Symbols $* * *, * *, *$ indicate significance at 1,5 , and 10 percent or less. Variable definitions are provided in the Appendix. 
Table 2 (continued)

Panel C: CIPO and CRM firm-years

(374 Chinese firm-years and 448 U.S. firm-years)

\begin{tabular}{|c|c|c|c|c|c|c|c|}
\hline & & ests 0 & erence & & & & \\
\hline & Mean & $\mathrm{T}$ & Chi & Std. dev. & Q1 & Median & Q3 \\
\hline 302 REPORT OF IIC & & & & & & & \\
\hline CIPO firm-years & 0.155 & & $* * *$ & 0.362 & 0.000 & 0.000 & 0.000 \\
\hline CRM firm-years & 0.491 & & & 0.500 & 0.000 & 0.000 & 1.000 \\
\hline GROWTH & & & & & & & \\
\hline CIPO firm-years & 6.115 & & & 3.223 & 4.000 & 8.000 & 9.000 \\
\hline CRM firm-years & 6.127 & & & 3.267 & 4.000 & 8.000 & 9.000 \\
\hline BUSSEGS & & & & & & & \\
\hline CIPO firm-years & 1.660 & $* *$ & & 1.181 & 1.000 & 1.000 & 2.000 \\
\hline CRM firm-years & 1.891 & & & 1.468 & 1.000 & 1.000 & 3.000 \\
\hline INVENTORY & & & & & & & \\
\hline CIPO firm-years & 0.049 & $* * *$ & & 0.073 & 0.000 & 0.012 & 0.079 \\
\hline CRM firm-years & 0.104 & & & 0.101 & 0.023 & 0.078 & 0.155 \\
\hline $\mathrm{MVE}^{\mathrm{a}}$ & & & & & & & \\
\hline CIPO firm-years & $1,069.3$ & $* * *$ & & $3,431.2$ & 114.8 & 321.6 & $1,042.2$ \\
\hline CRM firm-years & 124.5 & & & 146.3 & 28.7 & 68.0 & 161.3 \\
\hline ASSETS $^{a}$ & & & & & & & \\
\hline CIPO firm-years & 740.7 & $* * *$ & & 986.8 & 198.7 & 374.0 & 863.4 \\
\hline CRM firm-years & 207.4 & & & 283.4 & 72.9 & 126.8 & 235.0 \\
\hline RANK-Z & & & & & & & \\
\hline CIPO firm-years & 5.770 & & & 2.479 & 4.000 & 6.000 & 8.000 \\
\hline CRM firm-years & 5.650 & & & 2.383 & 4.000 & 6.000 & 8.000 \\
\hline FOREIGN & & & & & & & \\
\hline CIPO firm-years & 0.369 & & $* * *$ & 0.483 & 0.000 & 0.000 & 1.000 \\
\hline CRM firm-years & 0.266 & & & 0.442 & 0.000 & 0.000 & 1.000 \\
\hline RESTRUCTURE & & & & & & & \\
\hline CIPO firm-years & 0.032 & & $* * *$ & 0.176 & 0.000 & 0.000 & 0.000 \\
\hline CRM firm-years & 0.004 & & & 0.067 & 0.000 & 0.000 & 0.000 \\
\hline M\&A & & & & & & & \\
\hline CIPO firm-years & 0.433 & & $* * *$ & 0.496 & 0.000 & 0.000 & 1.000 \\
\hline CRM firm-years & 0.185 & & & 0.389 & 0.000 & 0.000 & 0.000 \\
\hline BIG4AUD & & & & & & & \\
\hline CIPO firm-years & 0.898 & & $* * *$ & 0.303 & 1.000 & 1.000 & 1.000 \\
\hline CRM firm-years & 0.087 & & & 0.282 & 0.000 & 0.000 & 0.000 \\
\hline LOSS & & & & & & & \\
\hline CIPO firm-years & 0.313 & & $* * *$ & 0.464 & 0.000 & 0.000 & 1.000 \\
\hline CRM firm-years & 0.225 & & & 0.418 & 0.000 & 0.000 & 0.000 \\
\hline
\end{tabular}


Table 3 Logistic regression tests of IIC differences

\begin{tabular}{|c|c|c|c|c|c|c|}
\hline \multirow{3}{*}{$\begin{array}{l}\text { Population } \\
\text { Dependent variable }\end{array}$} & \multirow{3}{*}{$\begin{array}{c}(1) \\
302 \text { Filers } \\
302\end{array}$} & (2) & (3) & \multirow{3}{*}{$\begin{array}{c}(4) \\
302 \text { Filers } \\
302\end{array}$} & \multirow{2}{*}{\multicolumn{2}{|c|}{$\begin{array}{l}\text { (5) } \\
\text { 404(b) Filers }\end{array}$}} \\
\hline & & \multicolumn{2}{|c|}{ 404(b) Filers } & & & \\
\hline & & 302 & 404(b) & & 302 & 404(b) \\
\hline \multirow[t]{2}{*}{ CIPO (H1) } & $0.831 * * *$ & 0.344 & $0.896 * * *$ & $0.555 * *$ & $0.742 *$ & $1.622 * * *$ \\
\hline & $(0.160)$ & $(0.240)$ & $(0.260)$ & $(\mathbf{0 . 2 3 8})$ & $(0.431)$ & $(0.540)$ \\
\hline \multirow[t]{2}{*}{ CRM (H1) } & $1.924 * * *$ & $2.135 * * *$ & $2.424 * * *$ & $1.772 * * *$ & $2.215 * * *$ & $2.753 * * *$ \\
\hline & $(\mathbf{0 . 1 2 3})$ & $(0.217)$ & $(\mathbf{0 . 2 3 3 )}$ & $(0.195)$ & $(0.436)$ & $(\mathbf{0 . 5 3 7 )}$ \\
\hline \multirow[t]{2}{*}{ USIPO } & -0.094 & 0.031 & -0.015 & $-0.744 * *$ & -0.724 & -0.642 \\
\hline & (0.090) & $(0.103)$ & (0.134) & $(0.352)$ & $(0.594)$ & $(0.806)$ \\
\hline \multirow{2}{*}{ USRM } & 0.487 & -0.179 & 0.175 & & & \\
\hline & $(0.461)$ & (1.166) & $(1.246)$ & & & \\
\hline \multirow[t]{2}{*}{ RANKGROWTH } & $0.035 * * *$ & -0.002 & 0.024 & $0.051 * *$ & -0.031 & -0.017 \\
\hline & $(0.011)$ & $(0.014)$ & $(0.018)$ & $(0.023)$ & $(0.043)$ & $(0.048)$ \\
\hline \multirow[t]{2}{*}{ BUSSEGS } & 0.029 & $0.049 *$ & $0.072 * *$ & 0.068 & $0.294 * * *$ & $0.267 * * *$ \\
\hline & $(0.022)$ & $(0.027)$ & $(0.035)$ & $(0.049)$ & $(0.091)$ & $(0.096)$ \\
\hline \multirow[t]{2}{*}{ FOREIGNSALES } & 0.099 & 0.056 & -0.017 & -0.183 & $-0.523^{*}$ & $-0.578^{*}$ \\
\hline & $(0.070)$ & $(0.092)$ & $(0.115)$ & $(0.149)$ & $(0.276)$ & $(0.306)$ \\
\hline \multirow{2}{*}{ RESTRUCTURE } & 0.027 & 0.036 & 0.090 & 0.000 & 0.400 & $0.943^{*}$ \\
\hline & $(0.077)$ & $(0.094)$ & $(0.121)$ & $(0.240)$ & $(0.409)$ & $(0.506)$ \\
\hline \multirow[t]{2}{*}{$M \& A$} & -0.061 & -0.065 & 0.036 & -0.145 & $-0.888 * * *$ & -0.433 \\
\hline & $(0.071)$ & $(0.087)$ & $(0.111)$ & $(0.161)$ & $(0.302)$ & $(0.317)$ \\
\hline \multirow{2}{*}{ BIG4AUD } & $-0.269 * * *$ & $-0.211 * *$ & $-0.310 * *$ & -0.158 & -0.097 & -0.288 \\
\hline & $(0.084)$ & $(0.105)$ & $(0.130)$ & $(0.200)$ & $(0.357)$ & $(0.397)$ \\
\hline \multirow[t]{2}{*}{ INVENTORY } & 0.202 & $1.609 * * *$ & $1.163^{*}$ & 0.669 & $2.751 * *$ & 2.180 \\
\hline & $(0.327)$ & $(0.506)$ & $(0.641)$ & $(0.646)$ & $(1.284)$ & $(1.452)$ \\
\hline \multirow[t]{2}{*}{ LNASSETS } & $-0.190 * * *$ & $-0.263 * * *$ & $-0.317 * * *$ & -0.081 & -0.219 & -0.276 \\
\hline & $(0.026)$ & $(0.036)$ & $(0.047)$ & $(0.077)$ & $(0.152)$ & $(0.169)$ \\
\hline \multirow[t]{2}{*}{ RANKZ } & $-0.094 * * *$ & $-0.096 * * *$ & $-0.117 * * *$ & $-0.137 * * *$ & $-0.243 * * *$ & $-0.181 * *$ \\
\hline & $(0.015)$ & $(0.019)$ & $(0.024)$ & $(0.033)$ & $(0.065)$ & $(0.071)$ \\
\hline \multirow[t]{2}{*}{ LOSS } & $0.535^{* * *}$ & $0.624 * * *$ & $0.564 * * *$ & $0.462 * * *$ & 0.343 & 0.233 \\
\hline & $(0.075)$ & $(0.096)$ & $(0.123)$ & $(0.175)$ & $(0.334)$ & $(0.369)$ \\
\hline \multirow[t]{2}{*}{ Constant } & $-1.021 * * *$ & $-1.285 * *$ & $-1.950 * * *$ & $-1.339 * *$ & -0.727 & -1.315 \\
\hline & $(0.380)$ & $(0.522)$ & $(0.606)$ & $(0.521)$ & (1.142) & (1.284) \\
\hline$C I P O=C R M(\mathrm{H3})$ & $31.56 * * *$ & $32.08 * * *$ & $20.45 * * *$ & $27.28 * * *$ & $11.89 * * *$ & $6.199 * *$ \\
\hline Observations & 14,041 & 11,034 & 11,034 & 1,580 & 750 & 750 \\
\hline Exchange dummies & YES & YES & YES & YES & YES & YES \\
\hline Industry dummies & YES & YES & YES & NO & NO & NO \\
\hline Likelihood ratio, $\chi^{2}$ & $1242.3 * * *$ & $589.7 * * *$ & $487.5^{* * *}$ & $296.2 * * *$ & $159.2 * * *$ & $131.1 * * *$ \\
\hline Wald, $\chi^{2}$ & $1024.5^{* * *}$ & $466.8 * * *$ & $427.1 * * *$ & $232.9 * * *$ & $109.0 * * *$ & $93.5 * * *$ \\
\hline Pseudo R-squared & 0.138 & 0.106 & 0.126 & 0.174 & 0.267 & 0.257 \\
\hline
\end{tabular}

Logistic regressions of equation (1) on different samples with the dependent variable 302 in columns (1), (2), (4), and (5); the dependent variable is 404(b) for columns (3) and (6). The samples are as follows: column (1) is our 302 filer sample; columns (2) and (3) are the 404(b) filer subsample; column (4) includes all CIPOs and CRMs and their matched firms; and columns (5) and (6) are a 404(b) filer matched subsample. Significance tests are Wald Chi-square tests except for CIPO=CRM, which presents the $F$-statistic for a Wald test of equal coefficients. Symbols ***,**,* indicate significance at 1,5, and 10 percent or less. Exchange indicators are NASDAQ, OTC, and PINK (intercept contains NYSE/AMEX). Fama-French 48 industry indicators are included and are individually dropped in the case of perfect multicollinearity. Variable definitions are provided in the Appendix. 
Table 4 Under-reporting of IICs, subsample of Chinese U.S.-listed firms and their matches

\begin{tabular}{|c|c|c|c|}
\hline \multirow{2}{*}{$\begin{array}{l}\text { Population } \\
\text { Dependent variable for each column } \\
\text { is UNDERREPORT_IIC }\end{array}$} & \multirow{2}{*}{$\begin{array}{c}(1) \\
302 \text { Filers } \\
302 \\
\end{array}$} & \multicolumn{2}{|c|}{$\begin{array}{l}\text { (2) } \\
\text { 404(b) Filers }\end{array}$} \\
\hline & & 302 & 404(b) \\
\hline CIPO (H3) & $\begin{array}{l}0.036 * * * \\
(0.004)\end{array}$ & $\begin{array}{c}0.001 \\
(0.007)\end{array}$ & $\begin{array}{c}0.006 \\
(0.005)\end{array}$ \\
\hline CRM (H3) & $\begin{array}{l}(0.043 * * * * \\
(0.009)\end{array}$ & $\begin{array}{l}0.051 * * \\
(0.021)\end{array}$ & $\begin{array}{l}0.054 * * * \\
(0.016)\end{array}$ \\
\hline USIPO & $\begin{array}{c}0.013^{*} \\
(0.007)\end{array}$ & $\begin{array}{c}0.011 \\
(0.012)\end{array}$ & $\begin{array}{c}0.010 \\
(0.009)\end{array}$ \\
\hline$B I G 4 A U D$ & $\begin{array}{l}-0.194 * * * \\
(0.007)\end{array}$ & $\begin{array}{l}-0.133 * * * \\
(0.018)\end{array}$ & $\begin{array}{l}-0.121 * * * \\
(0.014)\end{array}$ \\
\hline$D E B T$ & $\begin{array}{c}0.005 \\
(0.008)\end{array}$ & $\begin{array}{l}-0.020^{*} \\
(0.011)\end{array}$ & $\begin{array}{l}-0.013^{*} \\
(0.007)\end{array}$ \\
\hline SEO & $\begin{array}{c}0.017 \\
(0.011)\end{array}$ & $\begin{array}{c}0.046^{*} \\
(0.026)\end{array}$ & $\begin{array}{l}0.054 * * \\
(0.021)\end{array}$ \\
\hline$R O A$ & $\begin{array}{l}-0.132^{* * * *} \\
(0.016)\end{array}$ & $\begin{array}{l}-0.270 * * * \\
(0.037)\end{array}$ & $\begin{array}{l}-0.150 * * * \\
(0.027)\end{array}$ \\
\hline LITIGATION & $\begin{array}{l}-0.011 * * \\
(0.005)\end{array}$ & $\begin{array}{l}-0.019 * * \\
(0.007)\end{array}$ & $\begin{array}{l}-0.021 * * * \\
(0.005)\end{array}$ \\
\hline Constant & $\begin{array}{l}0.308^{* * *} \\
(0.007)\end{array}$ & $\begin{array}{l}0.230 * * * \\
(0.018)\end{array}$ & $\begin{array}{l}0.194 * * * \\
(0.015)\end{array}$ \\
\hline$C I P O=C R M(\mathrm{H} 4)$ & 0.509 & $5.932 * *$ & $9.209 * * *$ \\
\hline Observations & 1,219 & 648 & 670 \\
\hline R-squared & 0.627 & 0.400 & 0.453 \\
\hline
\end{tabular}

Ordinary least squares estimations of equation (3) on the subsample of CRM and CIPOs and their matches that disclose clean IIC reports, with robust standard errors reported below the coefficient estimates. The dependent variable is a prediction of the existence an IIC from equation (2) (the estimation of equation (2) is provided in Addendum 3). Column (1) includes all CIPOs and CRMs and their matched firms who report a clean 302 report; and columns (2) and (3) are the 404(b) filers from the matched sample who report a clean 302 and 404(b) report, respectively. Significance based on $t$-statistics are presented except for CIPO=CRM, which presents the $F$-statistic for a Wald test of equal coefficients. Symbols ***, **, * indicate significance at 1, 5, and 10 percent or less. Variable definitions are provided in the Appendix. 
Table 5 Effect of scrutiny on reporting of IICs

\begin{tabular}{|c|c|c|c|}
\hline \multirow{3}{*}{$\begin{array}{l}\text { Population } \\
\text { Dependent variable }\end{array}$} & \multirow{3}{*}{$\begin{array}{c}(1) \\
302 \text { Filers } \\
302\end{array}$} & \multirow{2}{*}{\multicolumn{2}{|c|}{$\begin{array}{l}\text { (2) } \\
\text { 404(b) Filers }\end{array}$}} \\
\hline & & & \\
\hline & & 302 & 404(b) \\
\hline \multirow[t]{2}{*}{ CIPO } & 0.343 & 0.280 & $1.060 * * *$ \\
\hline & $(0.302)$ & $(0.372)$ & $(\mathbf{0 . 3 8 4})$ \\
\hline \multirow[t]{2}{*}{ CRM } & $1.244 * * *$ & $1.611 * * *$ & $1.997 * * *$ \\
\hline & $(\mathbf{0 . 1 7 8})$ & $(0.314)$ & $(\mathbf{0 . 3 3 5})$ \\
\hline \multirow[t]{2}{*}{ USIPO } & -0.078 & 0.050 & -0.018 \\
\hline & $(0.090)$ & $(0.103)$ & $(0.134)$ \\
\hline \multirow[t]{2}{*}{ USRM } & 0.542 & -0.128 & 0.147 \\
\hline & $(0.465)$ & $(1.198)$ & $(1.251)$ \\
\hline \multirow[t]{2}{*}{ SCRUTINY } & $-0.300 * * *$ & $-0.298 * * *$ & -0.002 \\
\hline & $(0.066)$ & $(0.083)$ & $(0.108)$ \\
\hline \multirow[t]{2}{*}{ CIPOXSCRUTINY } & $0.750 * *$ & 0.157 & -0.278 \\
\hline & $(0.344)$ & $(0.464)$ & $(0.484)$ \\
\hline \multirow{2}{*}{ CRMxSCRUTINY } & $1.180 * * *$ & $0.950 * *$ & $0.733 *$ \\
\hline & $(0.216)$ & $(0.391)$ & $(0.405)$ \\
\hline \multirow[t]{2}{*}{ RANKGROWTH } & $0.038 * * *$ & -0.001 & 0.026 \\
\hline & $(0.011)$ & $(0.014)$ & $(0.018)$ \\
\hline \multirow[t]{2}{*}{ BUSSEGS } & 0.028 & $0.048 *$ & $0.072 * *$ \\
\hline & $(0.022)$ & $(0.027)$ & $(0.035)$ \\
\hline \multirow[t]{2}{*}{ FOREIGNSALES } & 0.107 & 0.071 & -0.020 \\
\hline & $(0.070)$ & $(0.092)$ & $(0.115)$ \\
\hline \multirow{2}{*}{ RESTRUCTURE } & 0.022 & 0.023 & 0.092 \\
\hline & $(0.078)$ & $(0.094)$ & $(0.121)$ \\
\hline \multirow[t]{2}{*}{$M \& A$} & -0.059 & -0.065 & 0.034 \\
\hline & $(0.072)$ & $(0.087)$ & $(0.111)$ \\
\hline \multirow[t]{2}{*}{$B I G 4 A U D$} & $-0.266 * * *$ & $-0.218 * *$ & $-0.312 * *$ \\
\hline & $(0.084)$ & $(0.106)$ & $(0.130)$ \\
\hline \multirow[t]{2}{*}{ INVENTORY } & 0.214 & $1.606^{* * *}$ & $1.168 *$ \\
\hline & $(0.328)$ & $(0.506)$ & $(0.641)$ \\
\hline \multirow{2}{*}{ LNASSETS } & $-0.192 * * *$ & $-0.258 * * *$ & $-0.318 * * *$ \\
\hline & $(0.027)$ & $(0.036)$ & $(0.047)$ \\
\hline \multirow[t]{2}{*}{ RANKZ } & $-0.091 * * *$ & $-0.100 * * *$ & $-0.116^{* * *}$ \\
\hline & $(0.015)$ & $(0.019)$ & $(0.024)$ \\
\hline \multirow[t]{2}{*}{ LOSS } & $0.510 * * *$ & $0.582 * * *$ & $0.568 * * *$ \\
\hline & $(0.076)$ & $(0.097)$ & $(0.124)$ \\
\hline \multirow[t]{2}{*}{ Constant } & $-0.875^{* *}$ & $-1.088 * *$ & $-1.906 * * *$ \\
\hline & $(0.384)$ & $(0.519)$ & $(0.605)$ \\
\hline Observations & 14,041 & 11,034 & 11,034 \\
\hline Exchange/Industry dummies & YES/YES & YES/YES & YES/YES \\
\hline Likelihood ratio, $\chi^{2}$ & $1283.5^{* * *}$ & $605.8 * * *$ & $491.3 * * *$ \\
\hline Wald, $\chi^{2}$ & $1050.7 * * *$ & $481.4^{* * *}$ & $432.0 * * *$ \\
\hline Pseudo R-squared & 0.146 & 0.115 & 0.130 \\
\hline
\end{tabular}

Logistic regressions of equation (4), with the dependent variable 302 in columns (1) and (2) and 404(b) for column (3). Column (1) is our 302 filer sample and columns (2) and (3) are the 404(b) filer subsample. Significance tests are Wald Chi-square tests except for CIPOxSCRUTINY= CRMxSCRUTINY, which is the $F$-statistic for a Wald test of equal coefficients. Symbols $* * *, * * * *$ indicate significance at 1,5 , and 10 percent or less. Exchange indicators are NASDAQ, OTC, and PINK. Fama-French 48 industry indicators are included and are individually dropped in the case of perfect multicollinearity. Variable definitions are provided in the Appendix. 
Table 6 Auditors of Chinese U.S.-listed firms

Panel A: Chinese IPO firm-years ( $\mathrm{n}=374)$

\begin{tabular}{|c|c|c|c|c|c|c|c|c|}
\hline & $\begin{array}{l}\text { Count } \\
\text { Auditor name }\end{array}$ & Freq & $\%$ Freq & & $\begin{array}{l}\text { Fee } \\
\text { Auditor name }\end{array}$ & $\begin{array}{c}\text { Average fee } \\
\text { per Audit } \\
\text { (in } \$ 1,000)\end{array}$ & $\begin{array}{l}\text { Total fees } \\
\text { (in } \$ 1,000)\end{array}$ & $\begin{array}{c}\% \text { of } \\
\text { total fees }\end{array}$ \\
\hline 1 & Deloitte \& Touche LLP & 153 & $40.9 \%$ & 1 & Deloitte \& Touche LLP & $1,066.0$ & $163,099.5$ & $41.4 \%$ \\
\hline 2 & PricewaterhouseCoopers LLP & 84 & $22.5 \%$ & 2 & PricewaterhouseCoopers LLP & $1,428.3$ & $119,973.4$ & $30.4 \%$ \\
\hline 3 & Ernst \& Young LLP & 59 & $15.8 \%$ & 3 & Ernst \& Young LLP & 918.8 & $54,209.1$ & $13.8 \%$ \\
\hline 4 & KPMG LLP & 41 & $11.0 \%$ & 4 & KPMG LLP & $1,173.8$ & $48,125.3$ & $12.2 \%$ \\
\hline 5 & GHP Horwath PC & 6 & $1.6 \%$ & 5 & GHP Horwath PC & 214.3 & $1,286.0$ & $0.3 \%$ \\
\hline 6 & Kabani \& Company Inc & 5 & $1.3 \%$ & 6 & BDO China Dahua CPA Co Ltd & 622.5 & $1,245.0$ & $0.3 \%$ \\
\hline 7 & Grant Thornton LLP & 4 & $1.1 \%$ & 7 & Grant Thornton LLP & 284.6 & $1,138.5$ & $0.3 \%$ \\
\hline 8 & Friedman LLP & 3 & $0.8 \%$ & 8 & BDO China Shu Lun Pan CPAs LLP & 418.3 & 836.6 & $0.2 \%$ \\
\hline 8 & Crowe Horwath LLP & 3 & $0.8 \%$ & 9 & Kabani \& Company Inc & 142.6 & 713.0 & $0.2 \%$ \\
\hline 9 & Sherb \& Co LLP & 2 & $0.5 \%$ & 10 & BDO China Li Xin Da Hua CPA Co Ltd & 270.0 & 540.0 & $0.1 \%$ \\
\hline 9 & BDO China Li Xin Da Hua CPA Co Ltd & 2 & $0.5 \%$ & 11 & Friedman LLP & 178.3 & 535.0 & $0.1 \%$ \\
\hline 9 & Marcum Bernstein \& Pinchuk LLP & 2 & $0.5 \%$ & 12 & Crowe Horwath LLP & 178.0 & 534.0 & $0.1 \%$ \\
\hline 9 & BDO China Shu Lun Pan CPAs LLP & 2 & $0.5 \%$ & 13 & Stonefield Josephson Inc & 510.9 & 510.9 & $0.1 \%$ \\
\hline 9 & BDO China Dahua CPA Co Ltd & 2 & $0.5 \%$ & 14 & Marcum Bernstein \& Pinchuk LLP & 185.0 & 370.0 & $0.1 \%$ \\
\hline \multicolumn{9}{|c|}{ Panel B: Chinese reverse merger firm-years $(n=448)$} \\
\hline & $\begin{array}{l}\text { Count } \\
\text { Auditor name }\end{array}$ & Freq & $\%$ Freq & & $\begin{array}{l}\text { Fee } \\
\text { Auditor name }\end{array}$ & $\begin{array}{l}\text { Average fee } \\
\text { per Audit } \\
(\text { in } \$ 1,000)\end{array}$ & $\begin{array}{l}\text { Total fees } \\
\text { (in } \$ 1,000)\end{array}$ & $\begin{array}{c}\% \text { of } \\
\text { total fees }\end{array}$ \\
\hline 1 & BDO Limited CPAs (HK) & 22 & $4.9 \%$ & 1 & Deloitte \& Touche LLP & $1,125.1$ & $13,500.7$ & $9.5 \%$ \\
\hline 2 & Goldman Parks Kurland Mohidin & 21 & $4.7 \%$ & 2 & KPMG LLP & 782.5 & $10,955.3$ & $7.7 \%$ \\
\hline 3 & Friedman LLP & 18 & $4.0 \%$ & 3 & Weinberg \& Company & 679.5 & $8,833.7$ & $6.2 \%$ \\
\hline 3 & PKF Hong Kong & 18 & $4.0 \%$ & 4 & Ernst \& Young LLP & 725.3 & $7,252.7$ & $5.1 \%$ \\
\hline 3 & Marcum Bernstein \& Pinchuk LLP & 18 & $4.0 \%$ & 5 & Frazer Frost LLP & 444.5 & $7,112.2$ & $5.0 \%$ \\
\hline 6 & Moore Stephens Wurth Frazer \& Torbet & 16 & $3.6 \%$ & 6 & GHP Horwath PC & 521.5 & $6,258.0$ & $4.4 \%$ \\
\hline 6 & Frazer Frost LLP & 16 & $3.6 \%$ & 7 & BDO Limited CPAs (HK) & 283.0 & $6,226.3$ & $4.4 \%$ \\
\hline 8 & KPMG LLP & 14 & $3.1 \%$ & 8 & Moore Stephens Wurth Frazer \& Torbet & 374.6 & $5,993.5$ & $4.2 \%$ \\
\hline 9 & Weinberg \& Company & 13 & $2.9 \%$ & 9 & Marcum Bernstein \& Pinchuk LLP & 266.8 & $4,802.7$ & $3.4 \%$ \\
\hline 10 & Deloitte \& Touche LLP & 12 & $2.7 \%$ & 10 & PricewaterhouseCoopers LLP & $1,175.2$ & $4,700.7$ & $3.3 \%$ \\
\hline 10 & Sherb \& Co LLP & 12 & $2.7 \%$ & 11 & Grant Thornton LLP & 579.8 & $4,638.2$ & $3.3 \%$ \\
\hline 10 & Samuel H Wong \& Co LLP & 12 & $2.7 \%$ & 12 & Friedman LLP & 255.7 & $4,602.8$ & $3.2 \%$ \\
\hline 10 & GHP Horwath PC & 12 & $2.7 \%$ & 13 & Goldman Kurland \& Mohidin & 204.1 & $4,286.2$ & $3.0 \%$ \\
\hline 10 & Goldman Kurland \& Mohidin & 12 & $2.7 \%$ & 14 & Crowe Horwath HK CPA Ltd & 327.4 & $3,601.4$ & $2.5 \%$ \\
\hline 15 & Crowe Horwath HK CPA Ltd & 11 & $2.5 \%$ & 15 & PKF Hong Kong & 175.2 & $3,153.2$ & $2.2 \%$ \\
\hline 16 & Ernst \& Young LLP & 10 & $2.2 \%$ & & & & & \\
\hline 34 & PricewaterhouseCoopers LLP & 4 & $0.9 \%$ & & & & & \\
\hline
\end{tabular}


Addendum 1 Descriptive statistics for matched firm-years

Panel A: Firm-years for CIPOs and their matched counterparts ( $\mathrm{N}=373$ each)

\begin{tabular}{|c|c|c|c|c|c|c|c|}
\hline & & $\begin{array}{r}\text { Te } \\
\text { Diff } \\
\end{array}$ & & & & & \\
\hline & Mean & $\mathrm{T}$ & Chi & Std. dev. & Q1 & Median & Q3 \\
\hline 302 REPORT OF IIC & & & & & & & \\
\hline CIPO firm-years & 0.155 & & $* * *$ & 0.363 & 0.000 & 0.000 & 0.000 \\
\hline U.S.firm-years & 0.080 & & & 0.272 & 0.000 & 0.000 & 0.000 \\
\hline RANKGROWTH & & & & & & & \\
\hline CIPO firm-years & 6.107 & $* * *$ & & 3.224 & 4.000 & 8.000 & 9.000 \\
\hline U.S.firm-years & 4.381 & & & 2.814 & 2.000 & 5.000 & 7.000 \\
\hline BUSSEGS & & & & & & & \\
\hline CIPO firm-years & 1.660 & $* * *$ & & 1.182 & 1.000 & 1.000 & 2.000 \\
\hline U.S.firm-years & 1.962 & & & 1.429 & 1.000 & 1.000 & 3.000 \\
\hline INVENTORY & & & & & & & \\
\hline CIPO firm-years & 0.049 & $* * *$ & & 0.072 & 0.000 & 0.012 & 0.079 \\
\hline U.S.firm-years & 0.077 & & & 0.100 & 0.000 & 0.026 & 0.132 \\
\hline MVE $^{\mathrm{a}}$ & & & & & & & \\
\hline CIPO firm-years & 819.2 & $*$ & & $1,243.2$ & 114.8 & 320.5 & $1,042.2$ \\
\hline U.S.firm-years & 987.3 & & & $1,341.2$ & 171.5 & 437.0 & $1,231.2$ \\
\hline ASSETS $^{a}$ & & & & & & & \\
\hline CIPO firm-years & 729.3 & & & 917.1 & 198.7 & 375.3 & 863.4 \\
\hline U.S.firm-years & 722.7 & & & 923.9 & 201.4 & 370.2 & 884.3 \\
\hline RANKZ & & & & & & & \\
\hline CIPO firm-years & 5.761 & & & 2.477 & 4.000 & 6.000 & 8.000 \\
\hline U.S.firm-years & 5.584 & & & 2.473 & 4.000 & 6.000 & 8.000 \\
\hline FOREIGNSALES & & & & & & & \\
\hline CIPO firm-years & 0.367 & & $* * *$ & 0.483 & 0.000 & 0.000 & 1.000 \\
\hline U.S.firm-years & 0.649 & & & 0.478 & 0.000 & 1.000 & 1.000 \\
\hline RESTRUCTURE & & & & & & & \\
\hline CIPO firm-years & 0.032 & & $* * *$ & 0.177 & 0.000 & 0.000 & 0.000 \\
\hline U.S.firm-years & 0.375 & & & 0.485 & 0.000 & 0.000 & 1.000 \\
\hline $\mathrm{M} \& \mathrm{~A}$ & & & & & & & \\
\hline CIPO firm-years & 0.434 & & & 0.496 & 0.000 & 0.000 & 1.000 \\
\hline U.S.firm-years & 0.410 & & & 0.493 & 0.000 & 0.000 & 1.000 \\
\hline BIG4AUD & & & & & & & \\
\hline CIPO firm-years & 0.901 & & $* * *$ & 0.299 & 1.000 & 1.000 & 1.000 \\
\hline U.S.firm-years & 0.791 & & & 0.407 & 1.000 & 1.000 & 1.000 \\
\hline LOSS & & & & & & & \\
\hline CIPO firm-years & 0.314 & & & 0.465 & 0.000 & 0.000 & 1.000 \\
\hline U.S.firm-years & 0.290 & & & 0.454 & 0.000 & 0.000 & 1.000 \\
\hline
\end{tabular}

Panel B: Firm-years for CRMs and their matched counterparts ( $\mathrm{N}=417$ each)

\begin{tabular}{|c|c|c|c|c|c|c|c|}
\hline & \multicolumn{4}{|c|}{$\begin{array}{c}\text { Tests of } \\
\text { Differences }\end{array}$} & \multirow[b]{2}{*}{ Q1 } & \multirow[b]{2}{*}{ Median } & \multirow[b]{2}{*}{ Q3 } \\
\hline & Mean & $\mathrm{T}$ & Chi & Std. dev. & & & \\
\hline \multicolumn{8}{|l|}{302 REPORT OF IIC } \\
\hline CRM firm-years & 0.487 & & $* * *$ & 0.500 & 0.000 & 0.000 & 1.000 \\
\hline U.S.firm-years & 0.168 & & & 0.381 & 0.000 & 0.000 & 0.000 \\
\hline \multicolumn{8}{|l|}{ RANKGROWTH } \\
\hline CRM firm-years & 6.146 & $* * *$ & & 3.261 & 4.000 & 8.000 & 9.000 \\
\hline U.S. firm-years & 4.177 & & & 3.176 & 1.000 & 4.000 & 7.000 \\
\hline \multicolumn{8}{|l|}{ BUSSEGS } \\
\hline CRM firm-years & 1.868 & & & 1.471 & 1.000 & 1.000 & 3.000 \\
\hline U.S.firm-years & 1.909 & & & 1.249 & 1.000 & 1.000 & 3.000 \\
\hline \multicolumn{8}{|l|}{ INVENTORY } \\
\hline CRM firm-years & 0.105 & $* * *$ & & 0.099 & 0.023 & 0.074 & 0.154 \\
\hline U.S.firm-years & 0.163 & & & 0.130 & 0.050 & 0.144 & 0.240 \\
\hline \multicolumn{8}{|l|}{$\mathrm{MVE}^{\mathrm{a}}$} \\
\hline CRM firm-years & 127.6 & $* * *$ & & 144.8 & 29.5 & 70.0 & 163.8 \\
\hline U.S.firm-years & 198.7 & & & 318.5 & 22.9 & 80.8 & 225.2 \\
\hline \multicolumn{8}{|l|}{ ASSETS $^{a}$} \\
\hline CRM firm-years & 205.6 & & & 287.5 & 72.1 & 123.5 & 233.7 \\
\hline U.S.firm-years & 218.6 & & & 506.7 & 56.4 & 119.8 & 247.6 \\
\hline \multicolumn{8}{|l|}{ RANKZ } \\
\hline CRM firm-years & 5.669 & $* * *$ & & 2.380 & 4.000 & 6.000 & 8.000 \\
\hline U.S.firm-years & 4.681 & & & 2.699 & 2.000 & 5.000 & 7.000 \\
\hline \multicolumn{8}{|l|}{ FOREIGNSALES } \\
\hline CRM firm-years & 0.254 & & $* * *$ & 0.437 & 0.000 & 0.000 & 1.000 \\
\hline U.S.firm-years & 0.381 & & & 0.489 & 0.000 & 0.000 & 1.000 \\
\hline \multicolumn{8}{|l|}{ RESTRUCTURE } \\
\hline CRM firm-years & 0.002 & & $* * *$ & 0.048 & 0.000 & 0.000 & 0.000 \\
\hline U.S.firm-years & 0.266 & & & 0.445 & 0.000 & 0.000 & 1.000 \\
\hline \multicolumn{8}{|l|}{ M\&A } \\
\hline CRM firm-years & 0.182 & & $*$ & 0.385 & 0.000 & 0.000 & 0.000 \\
\hline U.S.firm-years & 0.235 & & & 0.427 & 0.000 & 0.000 & 0.000 \\
\hline \multicolumn{8}{|l|}{ BIG4AUD } \\
\hline CRM firm-years & 0.094 & & $* * *$ & 0.288 & 0.000 & 0.000 & 0.000 \\
\hline U.S.firm-years & 0.463 & & & 0.500 & 0.000 & 0.000 & 1.000 \\
\hline \multicolumn{8}{|l|}{ LOSS } \\
\hline CRM firm-years & 0.221 & & $* * *$ & 0.413 & 0.000 & 0.000 & 0.000 \\
\hline U.S.firm-years & 0.489 & & & 0.501 & 0.000 & 1.000 & 1.000 \\
\hline
\end{tabular}

${ }^{a}$ Winsorized, in millions. T and Chi are t-test and chi-square test significance, respectively. Symbols ***, **,* indicate significance at 1,5 , and 10 percent or less. Variable definitions are provided in the Appendix. 
Addendum 2 Pearson correlations for 302 filers (bottom 14,041 firm-years) and 404(b) filers (top 11,034 firm-years)

\begin{tabular}{|c|c|c|c|c|c|c|c|c|c|c|c|c|c|c|c|}
\hline & & 302 & A & B & $\mathrm{C}$ & $\mathrm{D}$ & $\mathrm{E}$ & $\mathrm{F}$ & G & $\mathrm{H}$ & I & $\mathrm{J}$ & K & $\mathrm{L}$ & M \\
\hline $404(b)$ & & & 0.14 & 0.01 & 0.20 & 0.02 & $(0.01)$ & $(0.04)$ & $(0.01)$ & $(\mathbf{0 . 0 3 )}$ & $(\mathbf{0 . 1 0})$ & 0.00 & $(0.06)$ & $(0.07)$ & $\mathbf{0 . 1 0}$ \\
\hline CHINA & A & 0.20 & & 0.22 & 0.55 & 0.12 & $(\mathbf{0 . 0 3})$ & $(0.08)$ & $(0.14)$ & $(0.01)$ & $(0.05)$ & $(0.06)$ & $(0.05)$ & 0.05 & 0.00 \\
\hline$I P O$ & B & $(0.02)$ & 0.16 & & $(0.06)$ & 0.16 & (0.14) & (0.10) & (0.12) & $(0.02)$ & 0.08 & (0.11) & (0.11) & 0.02 & 0.09 \\
\hline$R M$ & $\mathrm{C}$ & 0.24 & 0.71 & $(0.09)$ & & 0.08 & $(0.01)$ & $(0.06)$ & $(0.08)$ & $(0.04)$ & $(0.18)$ & 0.00 & $(0.04)$ & 0.02 & $(0.00)$ \\
\hline RANKGROWTH & $\mathrm{D}$ & 0.02 & 0.14 & 0.16 & 0.11 & & $(0.06)$ & $(\mathbf{0 . 0 3})$ & $(\mathbf{0 . 2 0})$ & 0.10 & $(0.06)$ & $(0.06)$ & 0.02 & 0.19 & (0.19) \\
\hline$B U S S E G S$ & $\mathrm{E}$ & $(\mathbf{0 . 0 3})$ & $(0.04)$ & (0.13) & $(0.02)$ & $(0.05)$ & & 0.05 & 0.08 & 0.15 & 0.06 & 0.01 & 0.10 & $(0.04)$ & (0.09) \\
\hline FOREIGNSALES & $\mathrm{F}$ & $(0.06)$ & (0.11) & $(0.07)$ & $(0.10)$ & $(0.02)$ & 0.05 & & 0.29 & 0.18 & 0.13 & 0.10 & 0.14 & 0.13 & (0.07) \\
\hline RESTRUCTURE & $\mathrm{G}$ & $(\mathbf{0 . 0 5})$ & $(\mathbf{0 . 1 7})$ & $(0.09)$ & (0.13) & (0.19) & 0.08 & 0.29 & & 0.11 & 0.14 & 0.03 & 0.07 & $(0.15)$ & 0.12 \\
\hline$M \& A$ & $\mathrm{H}$ & $(0.07)$ & $(0.05)$ & 0.02 & $(\mathbf{0 . 0 8})$ & 0.10 & 0.15 & 0.20 & 0.14 & & 0.07 & $(0.06)$ & 0.08 & 0.06 & $(0.12)$ \\
\hline$B I G 4 A U D$ & I & $(0.17)$ & $(\mathbf{0 . 1 5})$ & 0.15 & $(0.26)$ & $(0.02)$ & 0.08 & 0.21 & 0.21 & 0.16 & & $(\mathbf{0 . 0 3})$ & 0.14 & $(0.04)$ & $(0.05)$ \\
\hline INVENTORY & $\mathrm{J}$ & 0.01 & $(0.06)$ & $(0.12)$ & $(0.01)$ & $(0.08)$ & $(0.01)$ & 0.04 & $(0.01)$ & $(\mathbf{0 . 1 0})$ & $(\mathbf{0 . 1 3})$ & & $(0.06)$ & 0.22 & $(0.05)$ \\
\hline LNMARKETVAL & $\mathrm{K}$ & $(0.09)$ & $(0.07)$ & (0.09) & $(0.06)$ & 0.02 & 0.11 & 0.16 & 0.10 & 0.11 & 0.20 & $(0.08)$ & & 0.06 & (0.17) \\
\hline$R A N K Z$ & $\mathrm{~L}$ & $(0.10)$ & 0.07 & 0.03 & 0.04 & 0.21 & $(0.02)$ & 0.11 & (0.13) & 0.07 & 0.04 & 0.17 & 0.08 & & (0.37) \\
\hline LOSS & $\mathrm{M}$ & 0.13 & $(\mathbf{0 . 0 3})$ & 0.07 & $(\mathbf{0 . 0 3})$ & $(0.21)$ & $(0.09)$ & $(0.08)$ & 0.10 & $(0.13)$ & $(0.11)$ & $(0.01)$ & $(0.18)$ & $(0.42)$ & \\
\hline
\end{tabular}

Bolded correlations are significant at the 5 percent level or less. Variable definitions are provided in the Appendix. 
Addendum 3 First stage of under-reporting analysis

\begin{tabular}{|c|c|c|c|}
\hline \multirow{3}{*}{$\begin{array}{l}\text { Population } \\
\text { Dependent variables }\end{array}$} & \multirow{3}{*}{$\begin{array}{c}(1) \\
302 \text { Filers } \\
302\end{array}$} & (2) & (3) \\
\hline & & \multicolumn{2}{|c|}{ 404(b) Filers } \\
\hline & & 302 & 404(b) \\
\hline \multirow[t]{2}{*}{ RANKGROWTH } & $0.079 * * *$ & 0.015 & 0.042 \\
\hline & $(0.022)$ & $(0.040)$ & $(0.045)$ \\
\hline \multirow[t]{2}{*}{ BUSSEGS } & $0.081 *$ & $0.324 * * *$ & $0.292 * * *$ \\
\hline & $(0.047)$ & $(0.083)$ & $(0.088)$ \\
\hline \multirow[t]{2}{*}{ FOREIGNSALES } & -0.233 & $-0.487 *$ & $-0.583 * *$ \\
\hline & $(0.141)$ & $(0.259)$ & $(0.287)$ \\
\hline \multirow[t]{2}{*}{ RESTRUCTURE } & $-0.617 * * *$ & -0.532 & -0.537 \\
\hline & $(0.218)$ & $(0.325)$ & $(0.372)$ \\
\hline \multirow[t]{2}{*}{$M \& A$} & $-0.301 *$ & $-0.902 * * *$ & $-0.503^{*}$ \\
\hline & $(0.155)$ & $(0.290)$ & $(0.305)$ \\
\hline \multirow[t]{2}{*}{$B I G 4 A U D$} & $-0.946 * * *$ & $-0.890 * * *$ & $-0.935 * * *$ \\
\hline & $(0.161)$ & $(0.272)$ & $(0.289)$ \\
\hline \multirow[t]{2}{*}{ INVENTORY } & -0.111 & $3.223 * * *$ & $2.568 * *$ \\
\hline & $(0.591)$ & $(1.162)$ & $(1.277)$ \\
\hline \multirow[t]{2}{*}{ LNASSETS } & 0.045 & -0.182 & -0.198 \\
\hline & $(0.071)$ & $(0.145)$ & $(0.160)$ \\
\hline \multirow[t]{2}{*}{$R A N K Z$} & $-0.115^{* * *}$ & $-0.246 * * *$ & $-0.175 * * *$ \\
\hline & $(0.031)$ & $(0.061)$ & $(0.066)$ \\
\hline \multirow[t]{2}{*}{ LOSS } & $0.276^{*}$ & 0.242 & 0.148 \\
\hline & $(0.163)$ & $(0.310)$ & $(0.344)$ \\
\hline \multirow[t]{2}{*}{ Constant } & $-0.999 * *$ & 0.175 & -0.195 \\
\hline & $(0.484)$ & $(1.041)$ & $(1.132)$ \\
\hline Observations & 1,580 & 750 & 750 \\
\hline Exchange dummies & YES & YES & YES \\
\hline Industry dummies & NO & NO & NO \\
\hline Likelihood ratio, $\chi^{2}$ & $184 * * *$ & $121.2 * * *$ & $88.46 * * *$ \\
\hline Wald, $\chi^{2}$ & $158.4 * * *$ & $91.35 * * *$ & $75.15 * * *$ \\
\hline Pseudo R-squared & 0.108 & 0.203 & 0.174 \\
\hline
\end{tabular}

Logistic regressions of equation (2); the dependent variable is 302 in columns (1) and (2), and the dependent variable is 404(b) for column (3). Column (1) is our full sample and columns (2) and (3) are the 404(b) filer subsample. Significance tests are Wald Chi-square tests. Symbols ***, **, * indicate significance at 1, 5, and 10 percent or less. Exchange indicators are NASDAQ, OTC, and PINK (intercept contains NYSE/AMEX). Variable definitions are provided in the Appendix. 
Addendum 4 Matched univariate tests of differences in ICMW types

\begin{tabular}{|c|c|c|c|c|c|c|c|}
\hline \multicolumn{2}{|c|}{ Panel A: 302 filers } & $\begin{array}{c}\text { CIPO } \\
(n=373)\end{array}$ & \multicolumn{2}{|l|}{$\begin{array}{l}\text { Match } \\
(n=373)\end{array}$} & $\begin{array}{c}\text { CRM } \\
(n=437)\end{array}$ & \multicolumn{2}{|l|}{$\begin{array}{c}\text { Match } \\
(n=437)\end{array}$} \\
\hline Key & Accounting code descriptions & & & & & & \\
\hline 15 & Acc - Accounts/loans receivable, investments and cash issues & $3.22 \%$ & $1.34 \%$ & & $14.42 \%$ & $3.20 \%$ & $* * *$ \\
\hline 16 & Acc-PPE, intangible or fixed asset (value/diminution) issues & 1.61 & 1.61 & & 7.09 & 2.97 & $* * *$ \\
\hline 32 & Acc - Inventory, vendor, and cost of sales issues & 2.14 & 3.22 & & 11.67 & 6.41 & $* *$ \\
\hline 33 & Acc - Liabilities, payables, reserves and accrual estimate failures & 1.34 & 1.61 & & 9.84 & 5.26 & $* *$ \\
\hline 38 & Acc - Foreign, related party, affiliated and/or subsidiary issues & 3.75 & 2.41 & & 11.90 & 4.35 & $* * *$ \\
\hline 39 & Acc - Revenue recognition issues & 5.63 & 3.22 & & 9.84 & 6.64 & \\
\hline 40 & $\begin{array}{l}\text { Acc - Fin statement, footnote, US GAAP conversion, segment } \\
\text { disclosures }\end{array}$ & 10.72 & 1.07 & $* * *$ & 29.98 & 2.06 & $* * *$ \\
\hline 41 & Acc - Tax expense/benefit/deferral/other (FAS 109) issues & 1.88 & 3.22 & & 5.03 & 4.81 & \\
\hline 47 & Acc - Debt, quasi-debt, warrants, and equity (BCF) security issues & 1.34 & 0.54 & & 10.53 & 2.06 & $* * *$ \\
\hline \multirow[t]{2}{*}{68} & Acc - Unspecified/unidentified/inapplicable FASB/GAAP issues & 11.53 & 1.34 & $* * *$ & 31.81 & 6.86 & $* * *$ \\
\hline & Other code descriptions & & & & & & \\
\hline 49 & DC - Restatement (recent past or pending) evident & $0.80 \%$ & $2.95 \%$ & $*$ & $9.38 \%$ & $5.95 \%$ & \\
\hline 50 & DC - Financial close/policy/information accumulation/timeliness issues & 19.57 & 8.04 & $* * *$ & 53.32 & 18.31 & $* * *$ \\
\hline 51 & DC - Personnel inadequacies/segregation of duty issues & 25.74 & 6.17 & $* * *$ & 53.78 & 16.93 & $* * *$ \\
\hline 52 & DC - Information technology, software, access/security issues & 6.70 & 4.56 & & 9.38 & 9.38 & \\
\hline 53 & DC - Period-end close and non-routine adjustment issues & 3.75 & 4.56 & & 12.36 & 4.81 & $* * *$ \\
\hline 55 & DC - Remediation of disclosure control weakness asserted & 6.70 & 4.29 & & 4.35 & 5.03 & \\
\hline 56 & DC - Acquisition-related integration and/or challenges noted & 5.09 & 4.29 & & 8.92 & 6.41 & \\
\hline 63 & DC - Section 404 adverse report (recent past/pending) filed & 8.85 & 5.90 & & 48.51 & 15.79 & $* * *$ \\
\hline 70 & DC - Board, audit committee, corporate governance issues & 3.22 & 0.80 & $* *$ & 9.61 & 1.83 & $* * *$ \\
\hline 85 & DC - Fraud risk program/assessment/management & 1.61 & 0.54 & & 7.32 & 2.06 & $* * *$ \\
\hline \multicolumn{2}{|c|}{ Panel B: 404(b) filers } & $(n=262)$ & $(n=262)$ & & $(n=122)$ & $(n=122)$ & \\
\hline Key & Accounting code descriptions & & & & & & \\
\hline 15 & Acc - Accounts/loans receivable, investments and cash issues & $1.91 \%$ & $1.15 \%$ & & $18.64 \%$ & $5.08 \%$ & $* * *$ \\
\hline 16 & Acc-PPE, intangible or fixed asset (value/diminution) issues & 0.76 & - & & 13.56 & 3.39 & $* * *$ \\
\hline 32 & Acc - Inventory, vendor, and cost of sales issues & 1.91 & 2.67 & & 16.10 & 5.93 & $* *$ \\
\hline 33 & Acc - Liabilities, payables, reserves and accrual estimate failures & 0.38 & 1.15 & & 10.17 & 6.78 & \\
\hline 38 & Acc - Foreign, related party, affiliated and/or subsidiary issues & 3.44 & 1.53 & & 14.41 & 2.54 & $* * *$ \\
\hline 39 & Acc - Revenue recognition issues & 4.58 & 3.82 & & 7.63 & 5.08 & \\
\hline 40 & $\begin{array}{l}\text { Acc - Fin statement, footnote, US GAAP conversion, segment } \\
\text { disclosures }\end{array}$ & 5.73 & 0.38 & $* * *$ & 19.49 & 2.54 & $* * *$ \\
\hline 41 & Acc - Tax expense/benefit/deferral/other (FAS 109) issues & 0.76 & 2.29 & & 11.86 & 3.39 & $* *$ \\
\hline 47 & Acc - Debt, quasi-debt, warrants, and equity (BCF) security issues & 0.76 & - & & 11.86 & 0.85 & $* * *$ \\
\hline \multirow[t]{2}{*}{68} & Acc - Unspecified/unidentified/inapplicable FASB/GAAP issues & 3.82 & - & $* * *$ & 22.88 & 5.08 & $* * *$ \\
\hline & Other code descriptions & & & & & & \\
\hline 49 & DC - Restatement (recent past or pending) evident & $0.76 \%$ & $3.44 \%$ & $*$ & $12.71 \%$ & $6.78 \%$ & \\
\hline 50 & DC - Financial close/policy/information accumulation/timeliness issues & 9.16 & 6.11 & & 50.00 & 13.56 & $* * *$ \\
\hline 51 & DC - Personnel inadequacies/segregation of duty issues & 16.41 & 3.82 & $* * *$ & 52.54 & 12.71 & $* * *$ \\
\hline 52 & DC - Information technology, software, access/security issues & 3.82 & 3.82 & & 12.71 & 7.63 & \\
\hline 53 & DC - Period-end close and non-routine adjustment issues & 3.44 & 3.82 & & 13.56 & 1.69 & $* * *$ \\
\hline 55 & DC - Remediation of disclosure control weakness asserted & 6.87 & 3.05 & $*$ & 9.32 & 3.39 & \\
\hline 56 & DC - Acquisition-related integration and/or challenges noted & 5.73 & 3.05 & & 11.02 & 1.69 & $* * *$ \\
\hline 63 & DC - Section 404 adverse report (recent past/pending) filed & 6.49 & 4.96 & & 46.61 & 11.02 & $* * *$ \\
\hline 70 & DC - Board, audit committee, corporate governance issues & 1.15 & 0.76 & & 2.54 & 3.39 & \\
\hline 85 & DC - Fraud risk program/assessment/management & - & 0.38 & & 5.93 & 3.39 & \\
\hline
\end{tabular}

Symbols $* * *, * *, *$ indicates Fisher's exact test (two-sided) significance at 10, 5, or 1 percent or better. 